$\underline{\text { PNL-2278 }}$

UC-70

\title{
History of Prototype High Level Waste Canister SS-9 While in Air and Water Storage
}

\author{
by \\ D. J. Bradley
}

November 1977

Prepared for the U.S. Department of Energy under Contract EY-76-C-06-1830

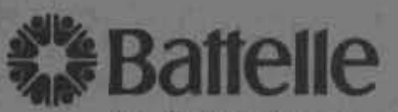

Pacific Northwest Laboratories 
This report was prepared as an account of work sponsored by the United States Covernment. Neither the United States nor the Department of Energy, nor any of their employees, nor any of their contractors, subcontractors, or their employees, makes any warranty, express or implied, or assumes any legal liability or responsibility for the accuracy, completeness or usefulness of any information, apparatus, product or process disclosed, or represents that its use would not infringe privately owned rights.

The views, opinions and conclusions contained in this report are those of the contractor and do not necessarily represent those of the United States Government or the United States Department of Energy.

\author{
PACIFIC NORTHWEST LABORATORY \\ operated by \\ BATTELLE \\ for the \\ UNITED STATES DEPARTMENT OF ENERGY \\ Under Contract EY-76-C-06-1830
}

\author{
Printed in the Unted States of America \\ Available from \\ Nationai Tectnical Intormation Service \\ Lnited States Department of Commerce \\ 5285 Fort Royal Road \\ Springileld, Virginia 22151
}

Price: Printed Copy s_; Microtiche $\$ 3.00$

$\begin{array}{cc} & \text { NTIS } \\ \text { Pesges } & \text { Sellins Price } \\ 001-025 & 54.50 \\ 026-050 & 55.00 \\ 057-075 & 55.50 \\ 075-700 & 56.00 \\ 101-125 & 56.50 \\ 126-150 & 57.00 \\ 157-175 & 57.75 \\ 176-200 & 50.50 \\ 201.225 & \$ 175 \\ 226-250 & 59.00 \\ 251-275 & 510.00 \\ 275-300 & 51025\end{array}$


PNL-2278

UC-70

HISTORY OF PROTOTYPE

HIGH LEVEL WASTE CANISTER SS-9

WHILE IN AIR AND WATER STORAGE

by

D. J. Bradley

November 1977

BATTELLE

Pacific Northwest Laboratories

Richland, Washington 99352 



\section{SUMMARY}

Canister SS-9 was filled with high-level phosphate ceramic waste material in March 1969. Following 1.2 years water storage at $50^{\circ} \mathrm{C}, 3.5$ years hot air storage at 400 to $500^{\circ} \mathrm{C}$, and 10 months water storage at $50^{\circ} \mathrm{C}$, the canister failed. The canister has three visible cracks, one of which is 13 in. long. It was concluded from metallography that failure was due to stress-assisted intergranular attack enhanced by metal sensitization during the hot air storage period, and a high chloride ion concentration in the canister storage water.

Cores were taken from Canister SS-9 and the leach rate of the material in deionized water was determined to be $5.1 \times 10^{-4} \mathrm{~g} / \mathrm{cm}^{2}$-day for the first day. Averaged over 90 days, the material leach rate was $3.1 \times 10^{-5} \mathrm{~g} / \mathrm{cm}^{2}$-day. Since it was known that the failure occurred sometime between quarterly canister storage water sampling periods, these leach rates were used to calculate an effective waste surface area presented by the canister cracks. Thus, the leach rates for the first day and the average for 90 days represent the extremes that could have occurred. The effective waste surface area contacted via the canister cracks was calculated to be between 1 and $20 \mathrm{~m}^{2}$.

Based on the calculated effective surface area and the above leach rates of the phosphate ceramic material, $6.1 \mathrm{~g}$ of waste were dissolved per day. This is related to the activity of the canister as follows:

- Curies of ${ }^{137}$ Cs in Canister SS-9 (corrected to May 1977) $=1.78 \times 10^{4}$

- Curjes of ${ }^{137} \mathrm{Cs}$ leached in one day, based on above leach rates

$$
\begin{aligned}
& =5.5 \times 10^{-1} \\
& =3.1 \times 10^{-3}
\end{aligned}
$$

Percent of total cesium in canister

- Curies of ${ }^{137} \mathrm{Cs}$ leached in one day based on averaged 90 th day leach rate and total canister surface area of $1.35 \mathrm{~m}^{2}$

$=1.41 \times 10^{-2}$

Percent of total cesium in canister

$=7.9 \times 10^{-5}$ 


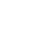

, 
CONTENTS

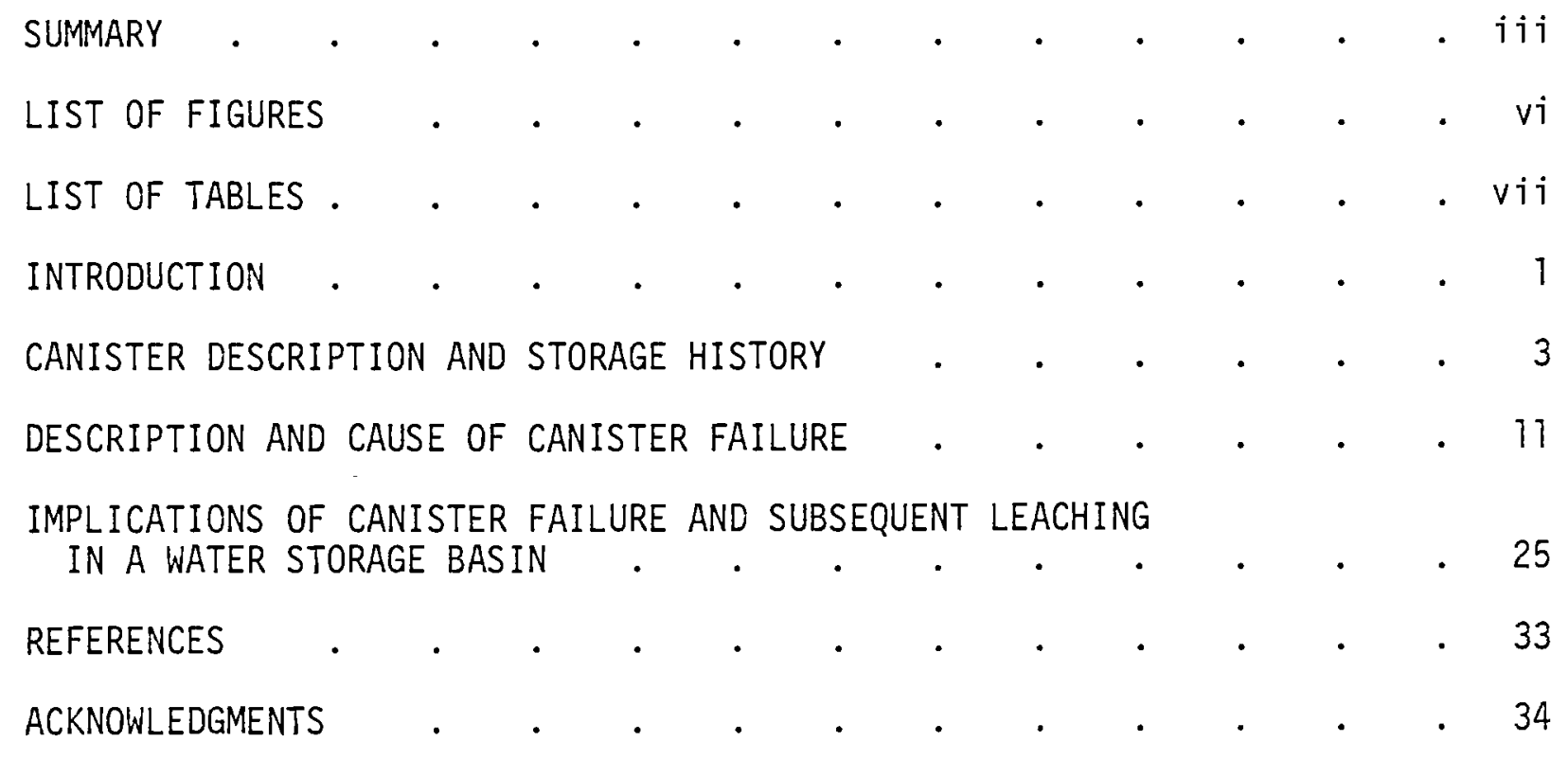

v 


\section{FIGURES}

1 Outline of WSEP Waste Solidification Process

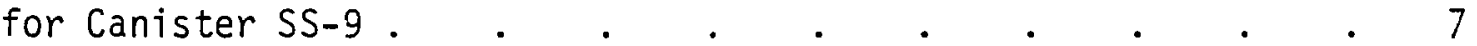

2 Environmental Test Pod for Nuclear Waste Containers . . 10

3 Canister S5-9 After Failure . . . . . . . . 12

4 Canister SS-9 Major Crack Before and After Cleaning . . . 13

5 Canister SS-9 Second and Third Cracks . . . . . . . 14

6 Location of Faiiure Areas . . . . . . . . . . 15

7 Core Samples Taken from Canister SS-9 . . . . . . . . 17

8 Photomicrographs of Canister Wall Section from WSEP Canister SS-9 - Sample Area

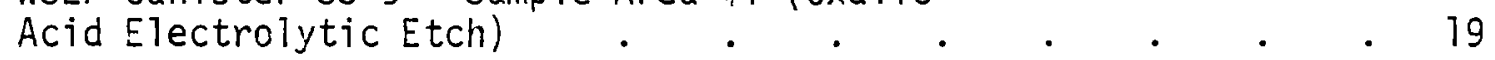

9 Photomicrographs of Canister Wall Section from WSEP Canister SS-9 - Sample Area $\$ 2$ (Oxalic Acid Electrolytic Etch) . . . . . . . . 20

10 Photomicrographs of Canister Wall Section from WSEP Canister SS-9 - Sample Area $\# 3$ (Oxalic Acid Electrolytic Etch) . . . . . . . . 21

11 Photomicrographs of Canister Wall Section from WSEP Canister SS-9 - Sample Area \#4 (Cxalic Acid Electrolytic Etch) . . . . . . . . 22

12 Photomicrographs of Canister wall Section from WSEP Canister SS-9 - Sample Area \#5 (Oxalic Acid Electrolytic Etch) . . . . . . . . 23

13 Core Samples for Leaching Experiments . . . . . . . 26

14 Paige Leaching Apparatus . . . . . . . . 27

15 Leach Rates of Canister SS-9 Phosphate Ceramic Waste . . . 29 


\section{TABLES}

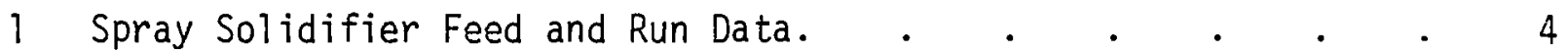

2 Chemical Compositions of High-Level Liquid Wastes for WSEP Demonstrations . . . . . . . . 5

3 Nominal Composition of Phosphate Ceramic Solidified

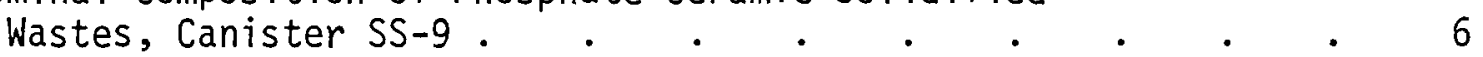

4 Major Radioisotope Content of Canister SS-9 . . . . . $\quad$. 8

5 Comparison of Canister SS-9 and Commercial Reactor Wastes . 8

6 Canister SS-9 Storage Pod Water Analysis . . . . . 99

7 Measurements Taken on Canister SS-9 Cracks . . . . . 11

8 Huey Test Data. . . . . . . . . . . . . 16

9 Locations of Metallographic Samples . . . . . . . 16

10 Canister SS-9 Core Sample Measurements . . . . . . 25

11 Leaching Schedule . . . . . . . . . . . . 25

12 Leach Rates of Canister SS-9 Phosphate Ceramic
Based on $137 \mathrm{CS}$

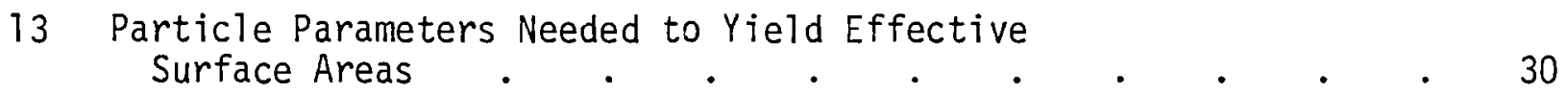

14 Water Storage Basin Acitivity from One Failed Canister
Based on $\{37 \mathrm{Cs}$. . . . 31 



\title{
HISTORY OF PROTOTYPE HIGH LEVEL \\ WASTE CANISTER SS-9 \\ WHILE IN AIR AND WATER STORAGE
}

\begin{abstract}
INTRODUCTION
This study investigates the history of a leak in a Waste Solidification Engineering Prototype (WSEP) high-level waste canister while in simulated water basin storage. The canister was a prototype fabricated of 310 stainless steel rather than the usual 304L stainless steel. The waste type was that of a phosphate ceramic material made as an early candidate for high level waste solidification. In this experimental program, the canister was subjected to a harsh storage history that would not be encountered in storage of full-scale high level waste canisters. The history of the canister (SS-9) is reviewed to give information on its filling and air and water storage conditions. The metallography of the canister failure is given, and the mechanism of containment breaching is postulated. The waste release from this failure is examined by means of data taken at the time of failure and recent leach test experiments on the waste material. The work discussed in this report was performed in the hot cell facilities of the 324 Building at the Pacific Northwest Laboratory.
\end{abstract}





\section{CANISTER DESCRIPTION AND STORAGE HISTORY}

During the week of March 22-27, 1969, a seamless 310 stainless steel canister (SS-9) was filled with a phosphate ceramic product containing $2 \times 10^{6}$ curies of radioactivity, as part of the Waste Solidification Engineering Prototypes program at the Pacific Northwest Laboratory (PNL). $(1,2)$

Table 1 shows the run characteristics for this canister. Tables 2 and 3 show the compositions of the feed and glass products, respectively. Figure 1 outlines the spray solidification process used to make Canister SS-9. The PW-4m waste composition was designed to represent that derived from high burnup fuels reprocessed by "clean" techniques of the future (e.g., no metal salt additives). Because power reactor fuel wastes were not available, the waste used for Canister SS-9 was manufactured by combining:

Constituent

1. Hanford Purex Plant High Leve] Waste specially prepared to have a low sulfate content. This is the acidic waste from the first extraction column.

2. Fission product rare earth concentrate, principally ${ }^{144} \mathrm{Ce}$

3. Nonradioactive chemicals
Purpose

Provide radioactive fission product spectrum, albeit at lower concentrations than in the nominal power reactor wastes, and typical nonradioactive Purex waste constituents, such as solvent degradation products.

Provide radionuclide decay heat equivalent to power reactor wastes. Increase chemical composition as required to equal nominal WSEP waste compositions shown in Table 2 .

This waste, al though not actual high exposure power reactor fuel waste, was considered to have been a good approximation for the study of solidification processing and interim storage for periods up to at least 10 years. The chemical stand-ins (Table 2) used for some of the more expensive fission products did not amount to more than 5.9 mole $\%$ of the content of the final 
TABLE 1. Spray Solidifier Feed and Run Data (2)

Solidified Run Number

SS-9

Date of Run

$3 / 22-27 / 69$

Canister Size, ID, cm

20.3

$\mathrm{PW}-4 \mathrm{~m}$

Type

Feed Volume, 1 iters/tonne

630

Feed Temperature, ${ }^{\circ} \mathrm{C}$

Feed Consumed, 1 iters

30

Total Feed Time, hr

Total Feed Time Off, hr

Average Feed Rate, 3 liter/hr

Bulk Density, $\mathrm{g} / \mathrm{cm}$

Volume of Product, liters

Fill Height, cm

Centerline

Temperature in Air, ${ }^{\circ} \mathrm{C}$

792

52

7.0

15.2

2.9

68.4

210.8

Wall Temperature in Air, ${ }^{\circ} \mathrm{C}$

594

352

Mass of Solidified Product, $\mathrm{kg}$

198.3

Radioactivity

Total Radioactivity in Feed to Calciner, (a) $\mathrm{KCi}$

2030

Total Radioactivity in

Canister, $\mathrm{KCi}$

Radioruthenium in Feed to

Calciner, $\mathrm{KCi}$

Feed Heat Rate Density, W/liter

Fission Product Heat to

Canister, $\mathrm{H}$

Ruthenium Volatilized, $\%$

$144 \mathrm{CePr}$ Entrainment from

Solidifier, (b)\%

2025

10.2

8.0

7200

57

0.023

Equivalant Spent Fuel Waste

Waste to Canister, tonne U equivalent.

1.26

Average Processing Rate,

Tonne/day

0.58

Equivalent Age of Waste, yr

2.3

(a) Radioactivity was predominately ${ }^{144} \mathrm{CePr}$.

(b) Based on heat generation rate in pod and ISOGEN program. 
TABLE 2. Chemical Compositions of High-Level Liquid Wastes for WSEP Demonstrations( 1 )

\begin{tabular}{|c|c|c|}
\hline & Constituent & $\begin{array}{c}\text { Concentration, Molarity } \\
\text { at } 378 \text { liters/tonne } \\
\text { PW-4m(a) }\end{array}$ \\
\hline $\begin{array}{l}\text { Nonfission } \\
\text { Products }\end{array}$ & $\begin{array}{l}\mathrm{H} \\
\mathrm{Fe} \\
\mathrm{Cr} \\
\mathrm{Ni} \\
\mathrm{AT} \\
\mathrm{Na} \\
\mathrm{U} \\
\mathrm{Hg} \\
\mathrm{NO}_{3} \\
\mathrm{PO}_{4} \\
\mathrm{SiO}_{3} \\
\mathrm{~F}\end{array}$ & $\begin{array}{c}0.50 \\
0.050 \\
0.012 \\
0.008 \\
0.001 \\
0.10 \\
0.010 \\
<0.001 \\
2.4 \\
0.003 \\
0.010 \\
<0.001\end{array}$ \\
\hline $\begin{array}{l}\text { Fission } \\
\text { Products }\end{array}$ & $\begin{array}{l}\text { Mo } \\
\mathrm{Tc}(\mathrm{Mo}) \\
\mathrm{Sr} \\
\mathrm{Ba} \\
\mathrm{Cs}(\mathrm{K}) \\
\mathrm{Rb}(\mathrm{K}) \\
\mathrm{Y}+\mathrm{RE} . \\
\mathrm{Zr} \\
\mathrm{Ru} \\
\mathrm{Ru}(\mathrm{Fe}) \\
\mathrm{Rh}(\mathrm{Co}) \\
\mathrm{Pd}(\mathrm{Ni}) \\
\mathrm{Ag}(\mathrm{Cu}) \\
\mathrm{Cd}(\mathrm{Cu}) \\
90 \mathrm{Sr} \\
106 \mathrm{Ru} \\
137 \mathrm{Cs} \\
144 \mathrm{Ce}\end{array}$ & $\begin{array}{l}0.130 \\
0.031 \\
0.036 \\
0.041 \\
0.078 \\
0.014 \\
0.27 \\
0.14 \\
0.0082 \\
0.0738 \\
0.013 \\
0.043 \\
0.0016 \\
0.0025 \\
0.0018 \\
0.00003 \\
0.0039 \\
0.0053\end{array}$ \\
\hline
\end{tabular}

Oxide Weight,

$\mathrm{kg} /$ tonne

Nonradioactive Chemicals

Fission Products

4.6

49.0

Total

53.6

(a) Fission product content corresponds to thermal reactor fuel exposures of $45,000 \mathrm{MWd} /$ tonne at $30 \mathrm{MW} /$ tonne, tonne $=1000 \mathrm{~kg} \mathrm{UO} 2$.

(b) Elements in parentheses were used as stand-ins for the more expensive fission products. 
TABLE 3. Nominal Composition of Phosphate Ceramic Solidified Wastes, (a) Canister SS-9(1)

\begin{tabular}{|c|c|}
\hline Component & $\mathrm{wt} \%$ \\
\hline $\mathrm{P}_{2} \mathrm{O}_{5}$ & 45.0 \\
\hline $\mathrm{SiO}_{2}$ & 0.1 \\
\hline $\mathrm{Na}_{2} \mathrm{O}$ & 7.5 \\
\hline $\mathrm{K}_{2} \mathrm{O}$ & 1.0 \\
\hline $\mathrm{Li}_{2} \mathrm{O}$ & 2.5 \\
\hline $\mathrm{Fe}_{2} \mathrm{O}_{3}$ & 18.2 \\
\hline $\mathrm{Al}_{2} \mathrm{O}_{3}^{(\mathrm{b})}$ & 2.0 \\
\hline $\mathrm{Cr}_{2} \mathrm{O}_{3}$ & 0.2 \\
\hline NiO & 0.9 \\
\hline $\mathrm{U}_{3} \mathrm{O}_{8}$ & 0.6 \\
\hline $\mathrm{Re}_{2} \mathrm{O}_{3}$ & 9.9 \\
\hline $\mathrm{ZrO}_{2}$ & 3.9 \\
\hline $\mathrm{MoO}_{3}$ & 5.1 \\
\hline $\mathrm{RuO}_{2}$ & 0.2 \\
\hline $\mathrm{Co}_{3} \mathrm{O}_{4}$ & 0.2 \\
\hline CuO & 0.1 \\
\hline Sro & 0.8 \\
\hline $\mathrm{BaO}$ & 1.4 \\
\hline${ }^{90}$ Sro & 0.046 \\
\hline${ }^{106} \mathrm{RuO}_{2}$ & 0.0009 \\
\hline${ }^{137} \mathrm{Cs}_{2} \mathrm{O}$ & 0.13 \\
\hline${ }^{144} \mathrm{CeO}_{2}$ & 0.22 \\
\hline retical wt\% Fissi & duct \\
\hline Oxides $(c)$ & 28.3 \\
\hline Specific Gravity & 3.0 \\
\hline
\end{tabular}

(a) Chemical stand-ins were used for some fission products. See Table 2.

(b) Representative $\mathrm{Al}_{2} \mathrm{O}_{3}$ concentrations in the radioactive products are shown in parentheses. The $\mathrm{A}_{2} \mathrm{O}_{3}$, nontypical of power reactor wastes, resulted from the simall and variable amounts of aluriinum unavoidably present in the Hanford Purex plant HLW used in preparing the WSEP wastes. In preparing the wastes for the WSEP radioactive runs the iron concentration was reduced in proportion to the aluminum present.

(c) Calculated on a no-substitution basis. 


\section{SPRAY CALCINER-MELTER}

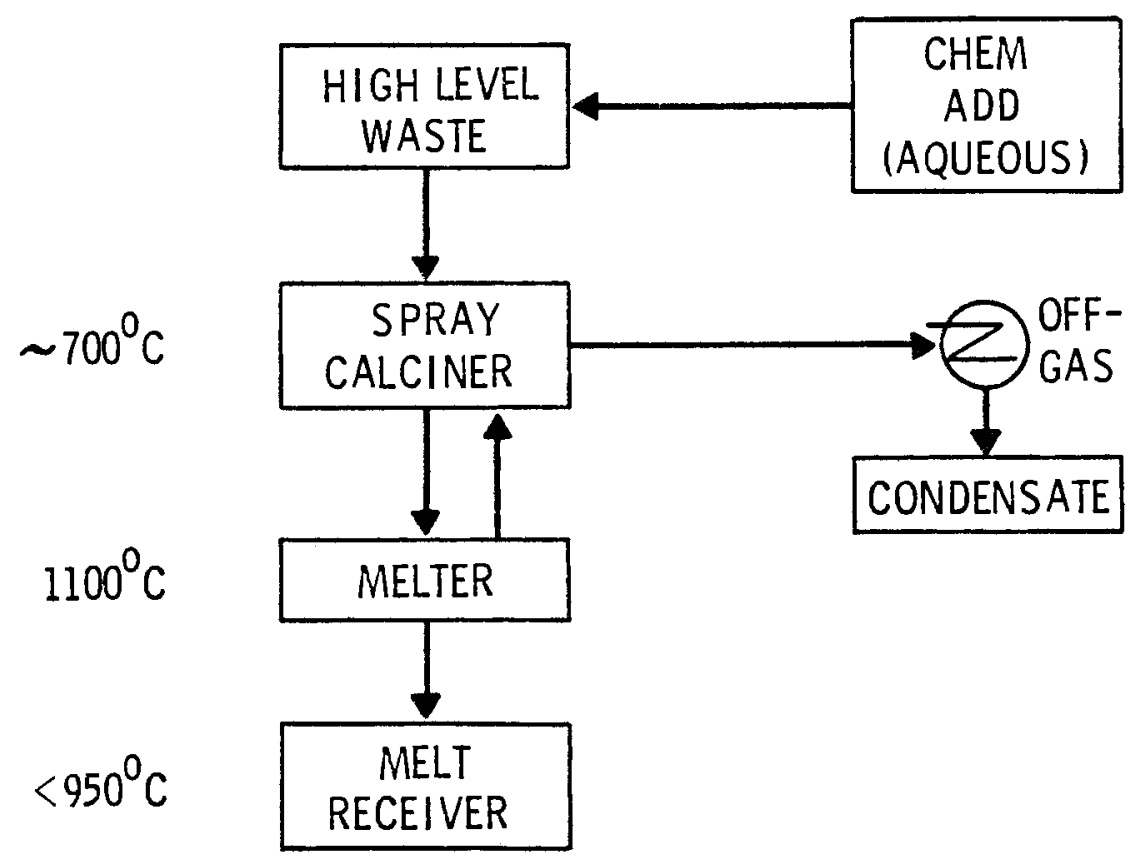

FIGURE 1. Outline of WSEP Waste Solidification Process for Canister SS-9

melt-formed solidified product. No effects attributable to the use of the chemical stand-ins were found in laboratory tests.

Table 4 shows an analysis of the major radioactive isotopes in a solidified waste sample taken from the SS-9 canister run in March 1969. This table also shows their decay corrected levels as of May 1977, when the last leach samples were analyzed. The predominant isotope in the SS-9 canister for the first 4.6 years was ${ }^{144} \mathrm{Ce}$. After this time, ${ }^{137} \mathrm{Cs}$, because of its much longer half-life, became the riajor radiation source.

As shown in Table 5 , radiation effects on the phosphate ceramic waste due to fission product decay should become apparent within 10 years because a very significant fraction of the total fission products present will decay in this period. The primary objective of the SS-9 run was to determine short-term decay effects, since no actinides were present in the waste. 
TABLE 4. Major Radioisotope Content of Canister SS-9

Per Gram

Phosphate Ceramic

March 1969

$\mathrm{Cs}^{137}$

$\mathrm{d} / \mathrm{min}$

$2.43 \times 10^{11}$

grams

curies $1.09 \times 10^{-1}$

$C e^{144}$

$\mathrm{d} / \mathrm{min}$

grams

curies

$\mathrm{Ru}^{106}$

$\mathrm{d} / \mathrm{min}$

grams

curies
$1.29 \times 10^{13}$

$1.82 \times 10^{-3}$

$5.81 \times 10^{0}$

$4.91 \times 10^{10}$

$6.61 \times 10^{-6}$

$2.21 \times 10^{-2}$

May 1977

$2.00 \times 10^{11}$

$1.05 \times 10^{-3}$

$8.99 \times 10^{-2}$

$7.23 \times 10^{9}$

$1.02 \times 10^{-6}$

$3.25 \times 10^{-3}$

$1.51 \times 10^{8}$

$2.03 \times 10^{-8}$

$6.78 \times 10^{-5}$

$9.73 \times 10^{15}$

$2.99 \times 10^{13}$

$1.31 \times 10^{0}$

$4.02 \times 10^{-3}$

$4.38 \times 10^{3}$

$1.34 \times 10^{1}$

TABLE 5. Comparison of Canister SS-9 and Commercial Reactor Wastes

\begin{tabular}{|c|c|c|}
\hline & $\begin{array}{c}\text { Canister SS-9, (a) } \\
\text { Curies } \\
\end{array}$ & $\begin{array}{c}\text { Commercial } \\
\text { Reactor Waste, } \\
\text { Curies } \\
\end{array}$ \\
\hline $\mathrm{Ru}^{106}$ & $4.4 \times 10^{3}$ & $1.3 \times 10^{5}$ \\
\hline $\mathrm{Cs}^{137}$ & $2.2 \times 10^{4}$ & $1.3 \times 10^{5}$ \\
\hline$C e^{144}$ & $1.2 \times 10^{6}$ & $1.6 \times 10^{5}$ \\
\hline $\begin{array}{l}\text { Total } \\
\text { Fission } \\
\text { Products } \\
\text { at } 2 \text { yr }\end{array}$ & $1.23 \times 10^{6}$ & $1.25 \times 10^{6}$ \\
\hline $\begin{array}{l}\text { Total } \\
\text { Fission } \\
\text { Products } \\
\text { at } 10 \mathrm{yr}\end{array}$ & $1.8 \times 10^{4}$ & $3.06 \times 10^{5}$ \\
\hline
\end{tabular}

(a) For 1.26 MTU equivalent at 2 yr age.

(b) For 1.26 MTU reprocessed, 33,000 MWD/MTU at 2 yr age. 
Following the end of the S5-3 run, the canister was stored in water at $50^{\circ} \mathrm{C}$ for 1.2 years, then transferred to an environmental test pod for hot air storage for 3.5 years. During this time, the wall temperature ranged between 400 and $500^{\circ} \mathrm{C}$. Figure 2 shows a cutaway view of the environmental test pod. In January 1974, the canister was placed in water storage at about $50^{\circ} \mathrm{C}$, also in an environmental test pod.

During October 1974, it became apparent that Canister SS-9 was leaking significantly. The evidence was seen as a sharp increase in the pod water activity, which is sampled on a quarterly basis. Representative pod water analyses prior to the leak are shown in Table 6 . Normally the pod water sample bottles read $1 \mathrm{mr} / \mathrm{hr}$. However, when the samples were taken on October 3, 1974, the water from the pod containing SS-9 read $250 \mathrm{mr} / \mathrm{hr}$.

TABLE 6. Canister SS-9 Storage Pod Water Analysis

\begin{tabular}{|c|c|c|c|c|}
\hline Sampled & $\mathrm{pH}$ & $\begin{array}{l}\mathrm{Cl}^{-1} \\
\mathrm{ppm}\end{array}$ & $\begin{array}{c}\mathrm{Cr}^{+6} \\
\mathrm{~g} / \mathrm{e} \\
\end{array}$ & $\begin{array}{l}137 \mathrm{Cs} \\
\mathrm{d} / \mathrm{min}-\mathrm{me}\end{array}$ \\
\hline $3 / 28 / 74$ & 7.6 & 9 & 0.209 & $4.02 \times 10^{5}$ \\
\hline $6 / 24 / 74$ & 7.4 & 12.7 & 0.518 & $4.00 \times 10^{5}$ \\
\hline
\end{tabular}

Several tests were run to verify the high water activity before the canister was removed from the pod. The pod was emptied and refilled with 416 \& of water. The water activity, as determined by a CP held next to $100 \mathrm{me}$ of water in a glass sample bottie, increased steadily:

- After $18 \mathrm{hr}$

$18 \mathrm{mr} / \mathrm{hr}$

- After $70 \mathrm{hr}$ $70 \mathrm{mr} / \mathrm{hr}$

- After $120 \mathrm{hr}$ $240 \mathrm{mr} / \mathrm{hr}$.

The general location of the leak was determined by incremental addition of water to the pod. This revealed the leak to be within the bottom $2 \mathrm{ft}$ of the canister. Following these tests the canister was removed from the pod and hung in the air for examination and drying. 


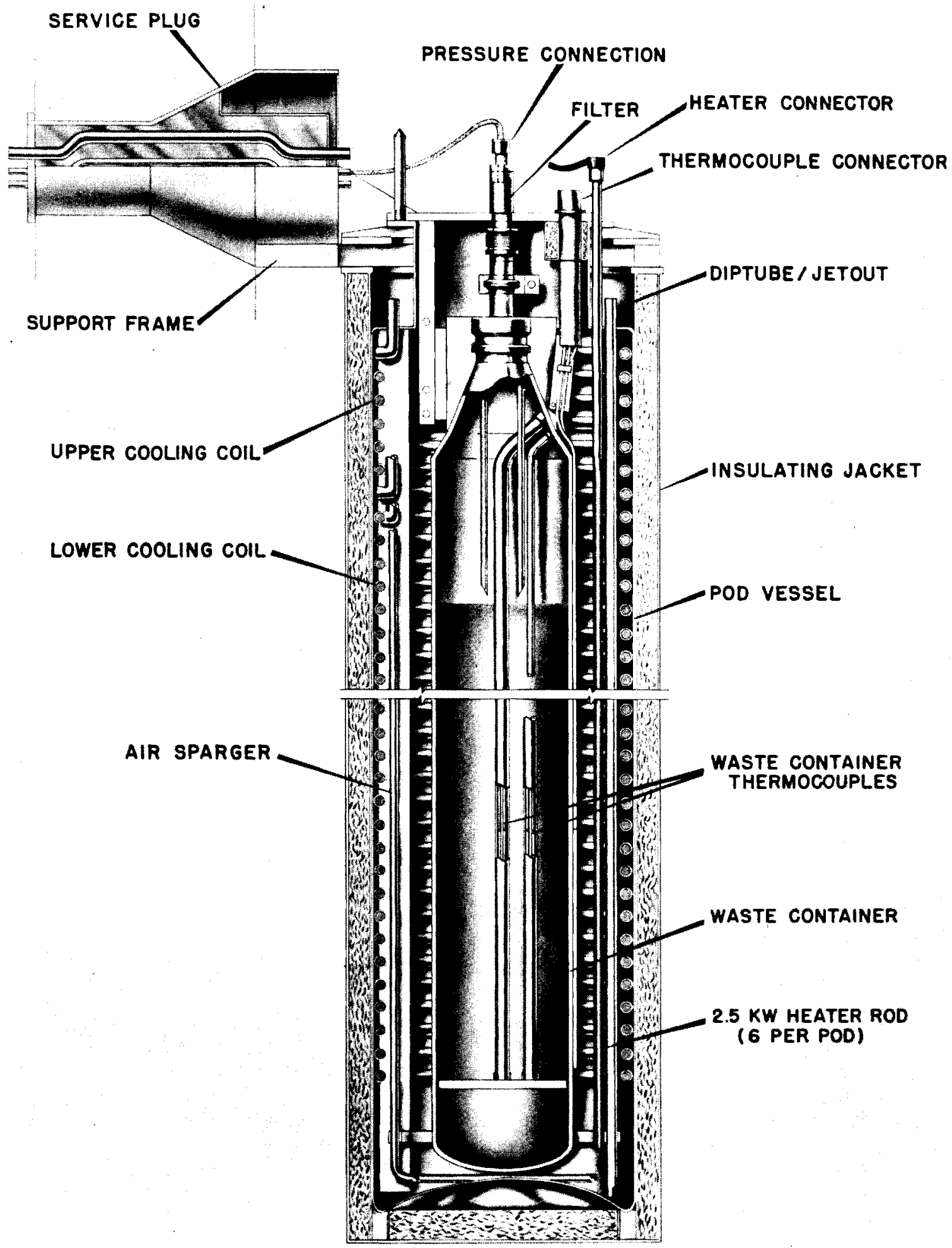

FIGURE 2. Environmental Test Pod for Nuclear Waste Containers 


\section{DESCRIPTION AND CAUSE OF CANISTER FAILURE}

Upon visual examination, the canister was seen to have three apparent cracks. Figure 3 shows the canister and the three areas that proved to be cracks. Figure 4 shows a close-up of the largest crack before and after cleaning by wire brush. The before-cleaning sequence follows the residue trail down below the bottom of the crack. Figure 5 shows the remaining two cracks. Figure 6 shows the canister with the locations of the cracks, and Table 7 gives data on the cracks.

\section{TABLE 7. Measurements Taken on Canister SS-9 Cracks

\begin{tabular}{|c|c|c|c|}
\hline & $\begin{array}{l}\text { Large } \\
\text { Crack }\end{array}$ & $\begin{array}{l}\text { Medium } \\
\text { Crack }\end{array}$ & $\begin{array}{l}\text { Sma 11 } \\
\text { Crack }\end{array}$ \\
\hline $\begin{array}{l}\text { Radial Angle }{ }^{(a)} \\
\text { Location, degrees }\end{array}$ & $100-107$ & 190 & 155 \\
\hline $\begin{array}{l}\text { Distance from } \\
\text { Bottom of Canister } \\
\text { to Start of Crack, } \\
\text { inches }\end{array}$ & $41 / 2$ & $31 / 2$ & $31 / 2$ \\
\hline $\begin{array}{l}\text { Length of Crack, } \\
\text { inches }\end{array}$ & 13 & $11 / 2$ & $1 / 2$ \\
\hline
\end{tabular}

(a) Indexed to thermocouple arm, see Figure 6 .

A sample was then core driiled from the canister for Huey testing (ASTM A-262, five 48-hr exposures to boiling $65 \% \mathrm{HNO}_{3}$ ), ${ }^{(4)}$ a standard test for sensitization of stainless steel. Since most of the canisters in the WSEP program were 304L, it was of interest to compare a $304 \mathrm{~L}$ sample taken from a canister stored in air for 2 years at $400^{\circ} \mathrm{C}$ after 1 year storage in water. (5) The results, given in Table 8 , show that both canisters were severely sensitized.

Five samples were then core drilled from canister SS-9 for metallcgraphic purposes. Tabie 9 gives the locations of these samples. 


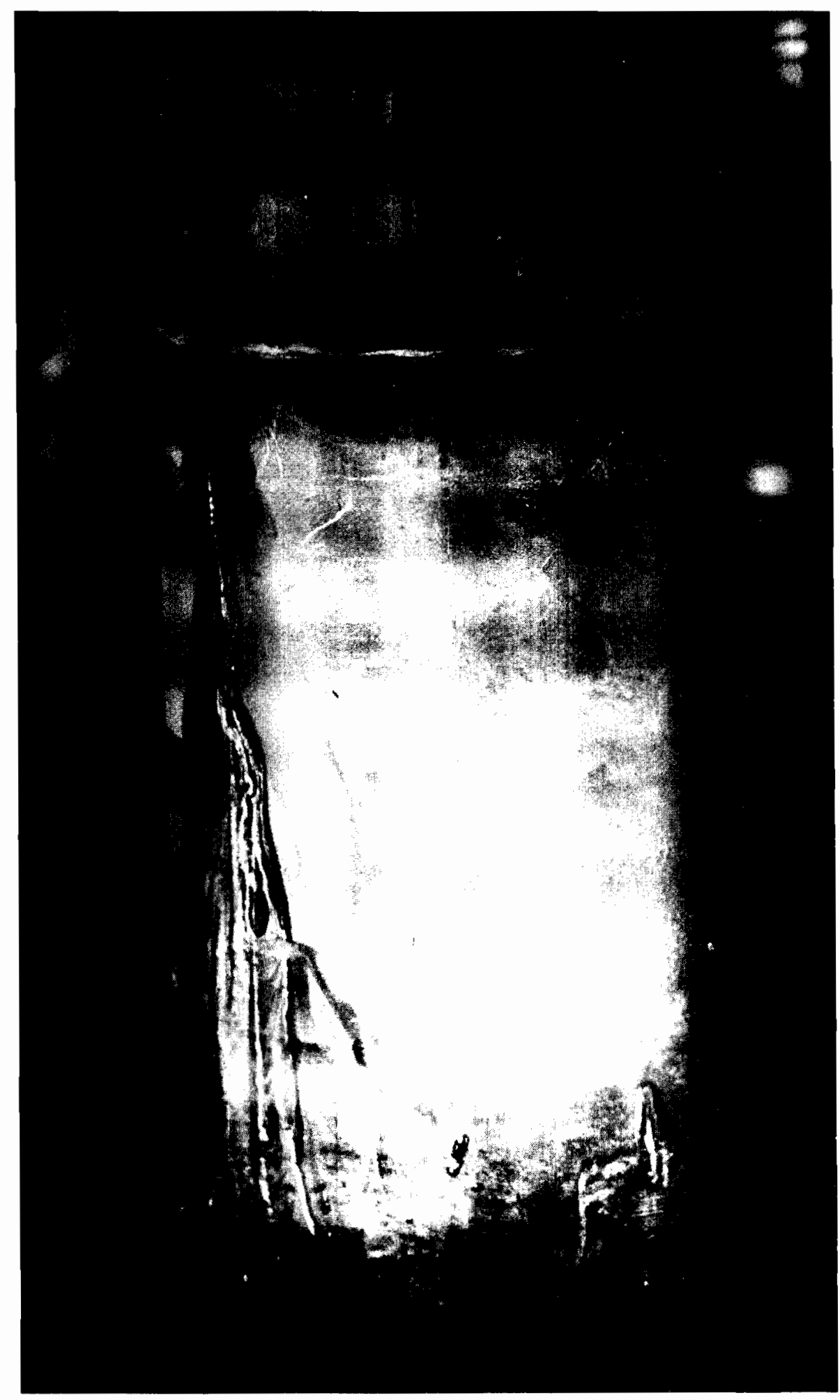

FIGURE 3. Canister SS-9 After Failure 

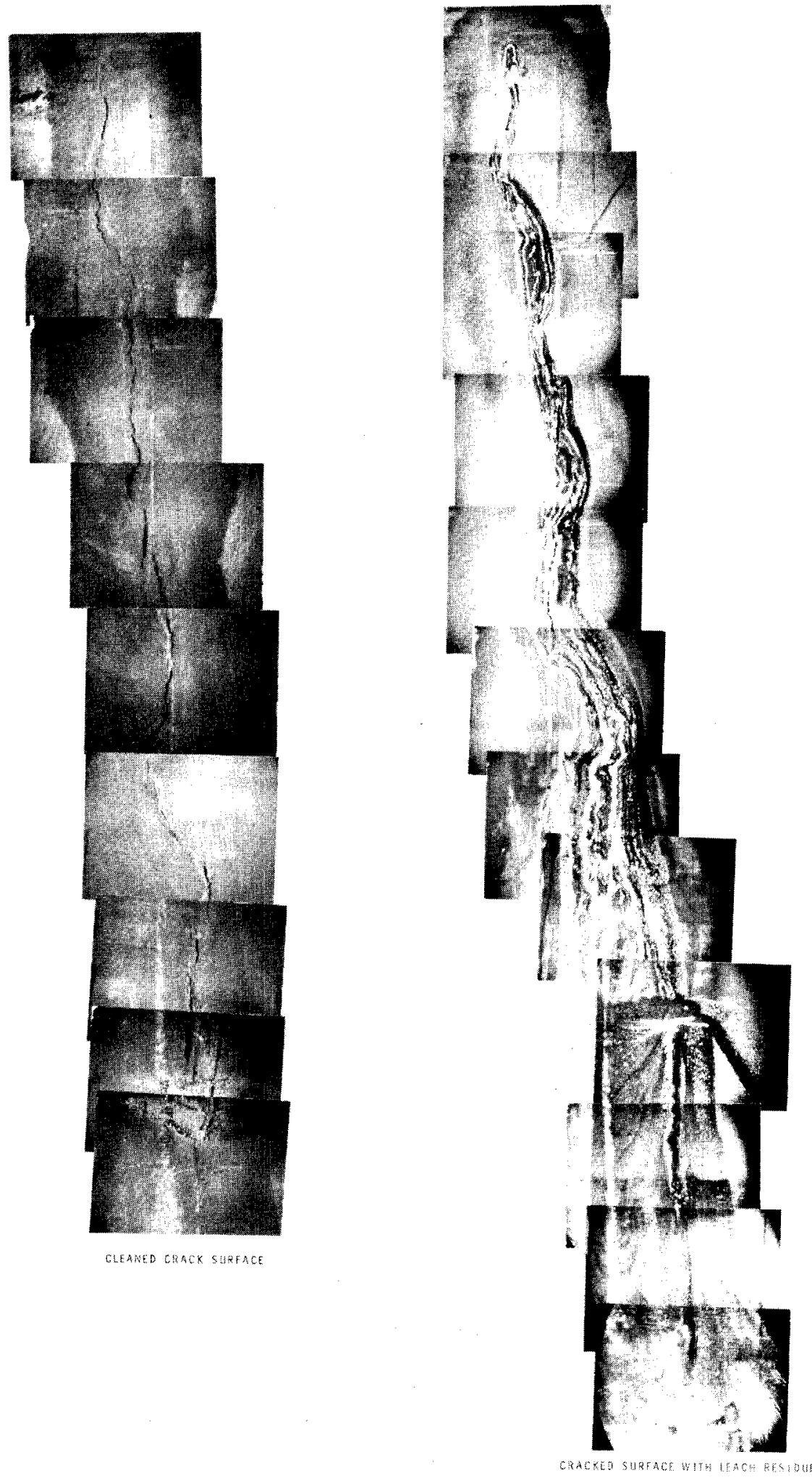

FIGURE 4. Canister SS-9 Major Crack Before and After Cleaning 


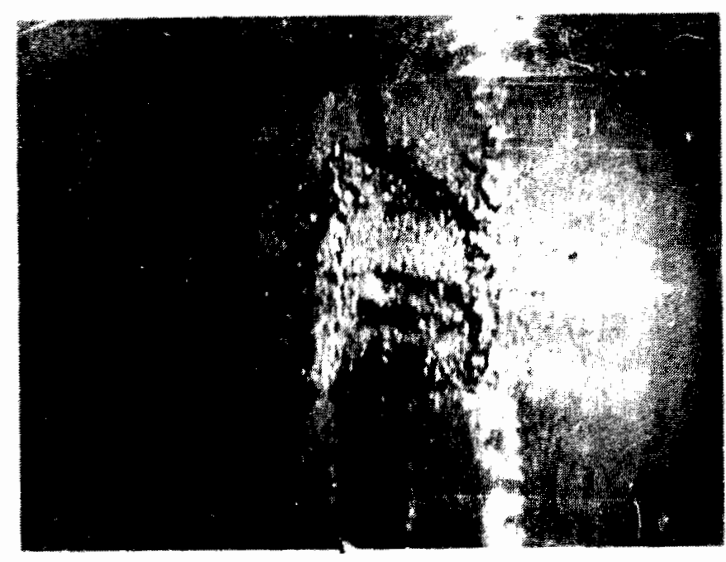

2ND CRACK

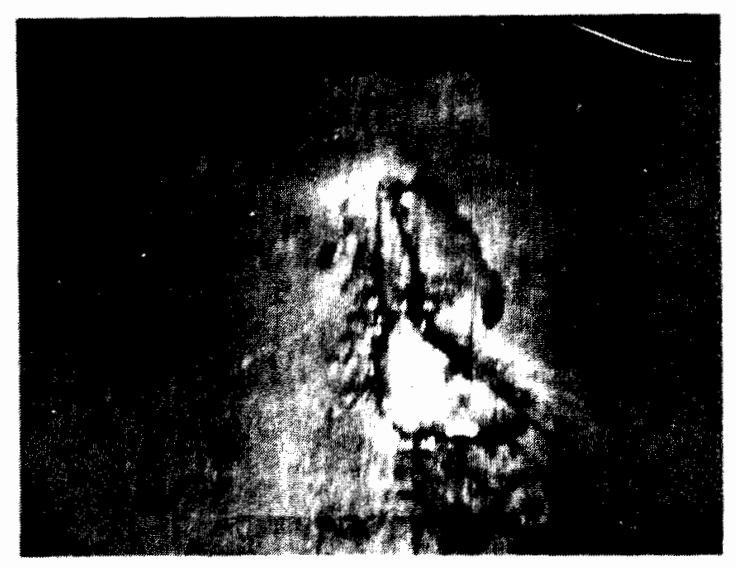

2ND CRACK CLEANED

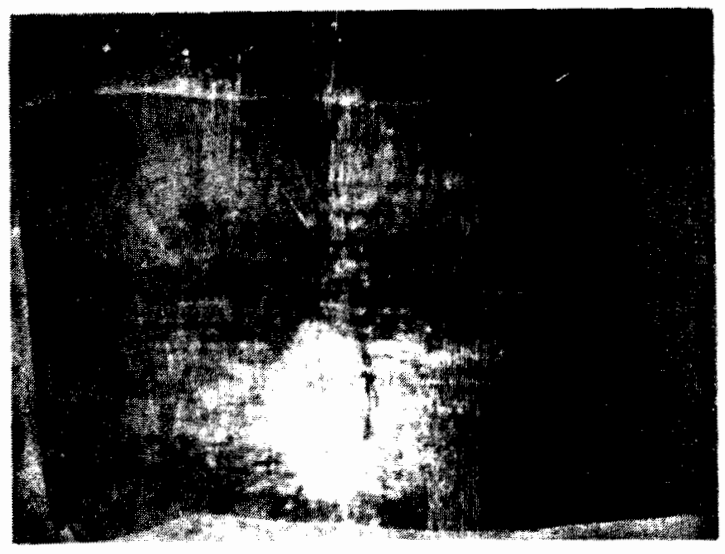

3RD CRACK

FIGURE 5. Canister SS-9 Second and Third Cracks 


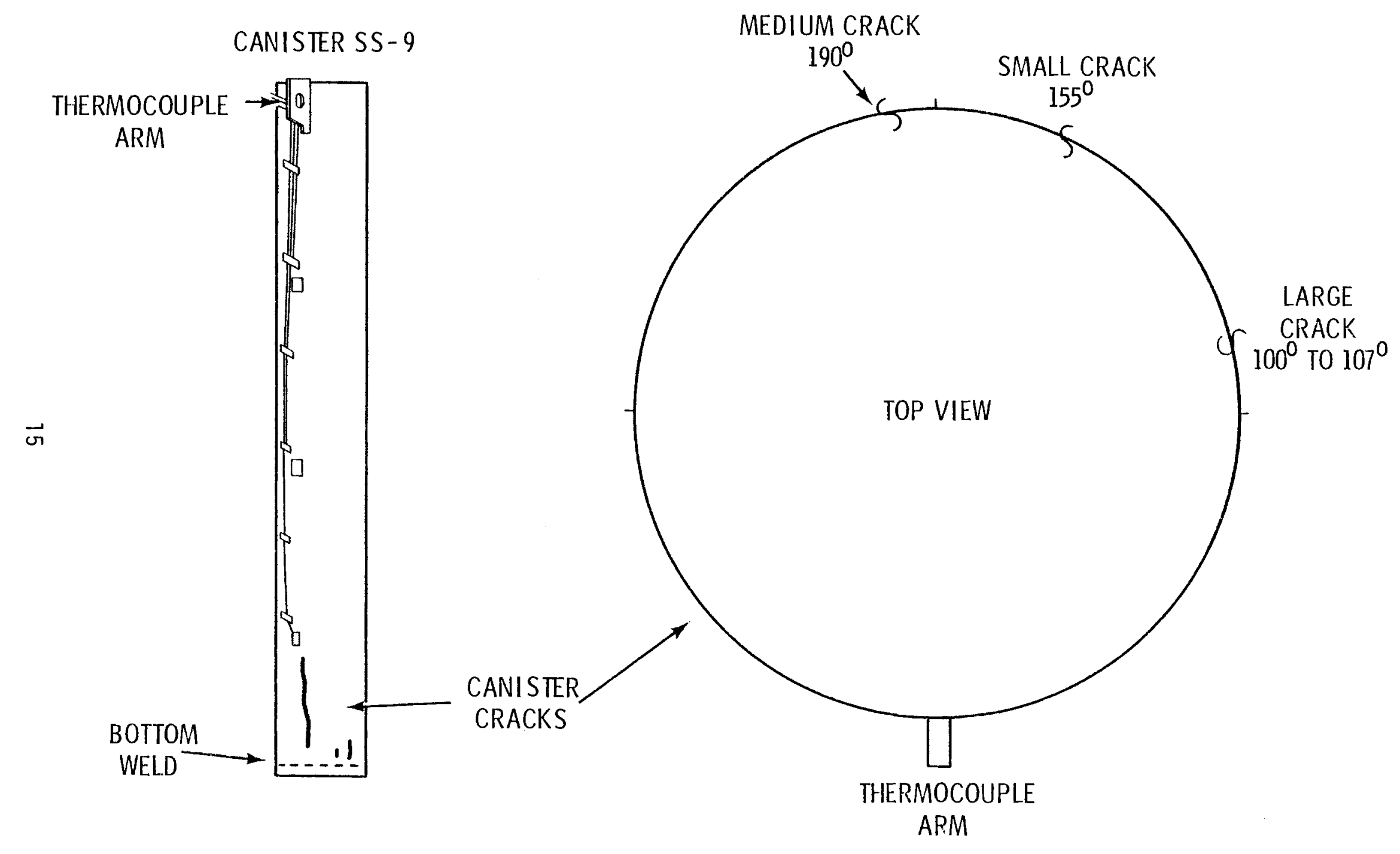

FIGURE 6. Location of Failure Areas 
TABLE 8. Huey Test Data

\begin{tabular}{|c|c|c|c|c|c|c|c|}
\hline \multirow{2}{*}{\multicolumn{2}{|c|}{ Material }} & \multicolumn{6}{|c|}{$\frac{\text { Corrosion Rate (mils/month) }}{\text { (a) }}$} \\
\hline & & 1 & 2 & 3 & 4 & 5 & $\underline{A v g}$ \\
\hline $304 \mathrm{~L}$ & Stainless Steel & 57 & 155 & 170 & 168 & 154 & 141 \\
\hline 310 & Stainless Steel & 45 & 180 & 207 & 222 & 209 & 173 \\
\hline
\end{tabular}

(a) The maximum rate for acceptable material is usually $2 \mathrm{mils} / \mathrm{mo}$ (avg).

TABLE 9. Locations of Metallographic Samples

\begin{tabular}{|c|c|c|c|}
\hline $\begin{array}{c}\text { Location } \\
\text { Number } \\
\end{array}$ & $\begin{array}{l}\text { Distance from Bottom } \\
\text { of Canister, in. }\end{array}$ & $\begin{array}{l}\text { Angle, }(a) \\
\text { in Degrees }\end{array}$ & Comments \\
\hline 1 & $131 / 2$ & 100 & $\begin{array}{l}\text { Section containing } \\
\text { top of large crack. }\end{array}$ \\
\hline 2 & $41 / 2$ & 107 & $\begin{array}{l}\text { Section near bottom } \\
\text { of large crack. }\end{array}$ \\
\hline 3 & 4 & 190 & $\begin{array}{l}\text { Contains part of } \\
\text { small crack and } \\
\text { bottom cap weld. }\end{array}$ \\
\hline 4 & $31 / 2$ & 255 & $\begin{array}{l}\text { From a bottom } \\
\text { section of the cap } \\
\text { weld. }\end{array}$ \\
\hline 5 & 10 & 300 & $\begin{array}{l}\text { From opposite side } \\
\text { of large crack. }\end{array}$ \\
\hline
\end{tabular}

(a) Indexed to thermocouple arm, see figure 6 .

Figure 7 shows these five samples after they were core drilled from the canister. Both the internal steel surface and its adjoining ceramic surface (external ceramic surface) are shcwn. These samples were then polished for metallographic examination of the longitudinal cross sections. Prior to viewing, the samples were electrolytically etched in oxalic acid. 

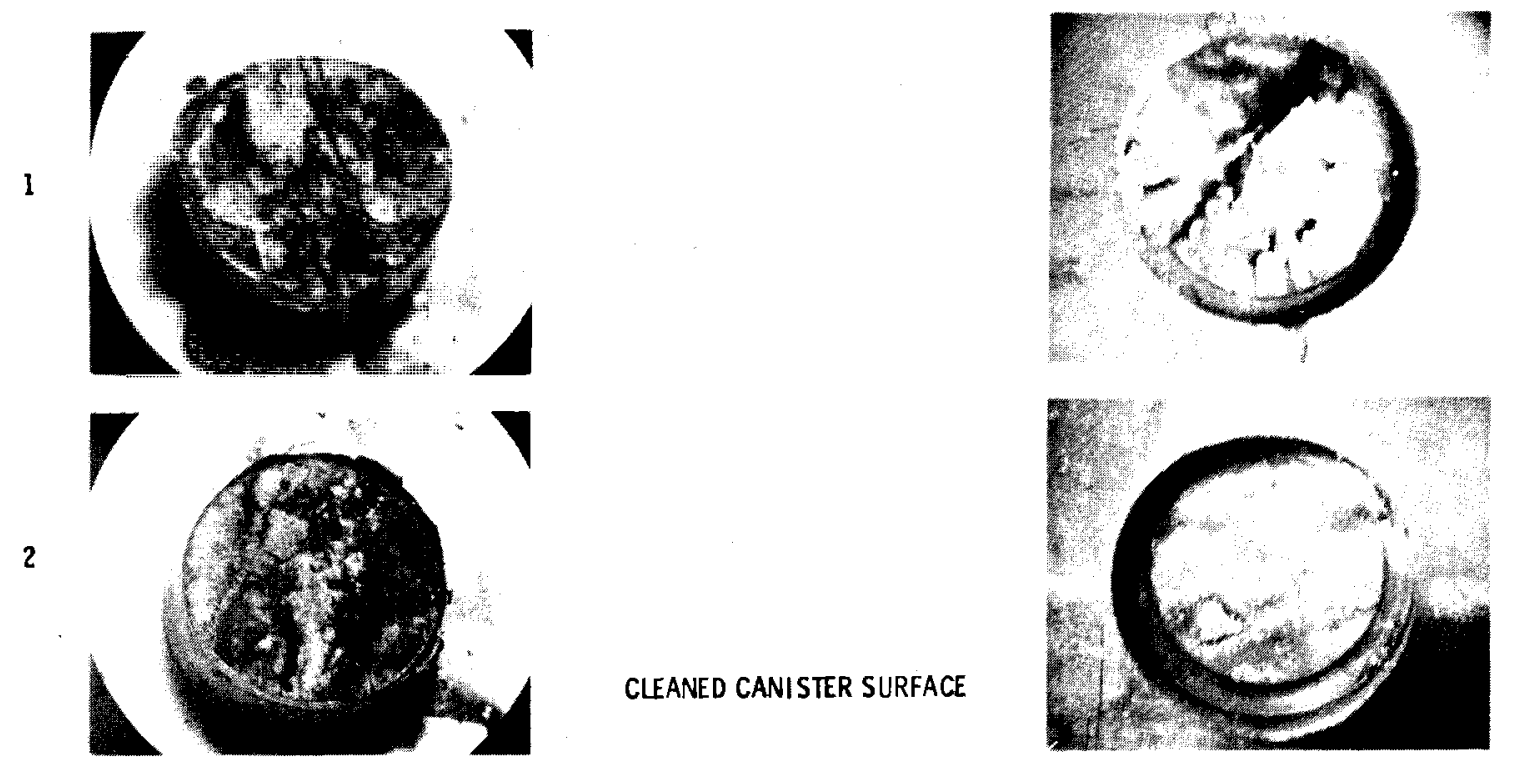

CLEANED CANISTER SURFACE
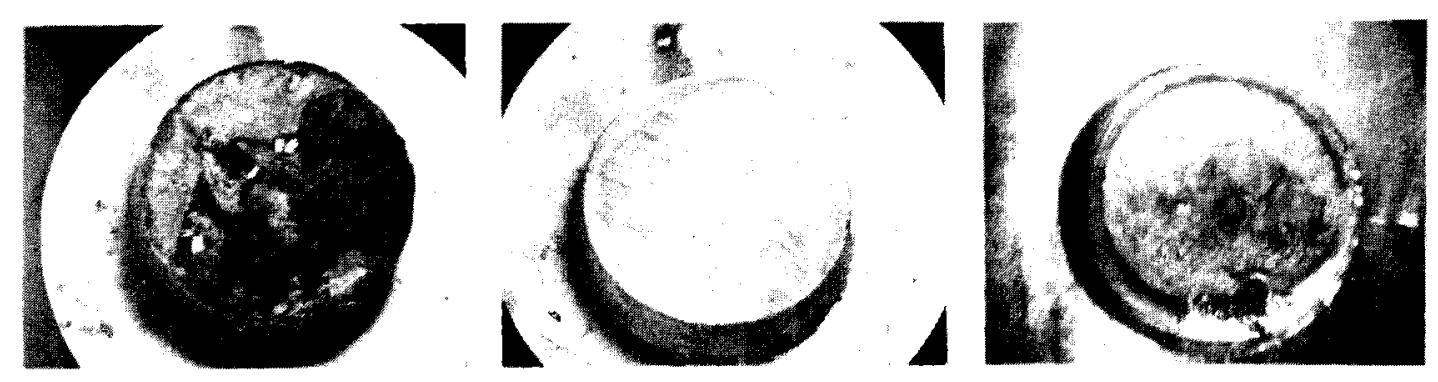

3
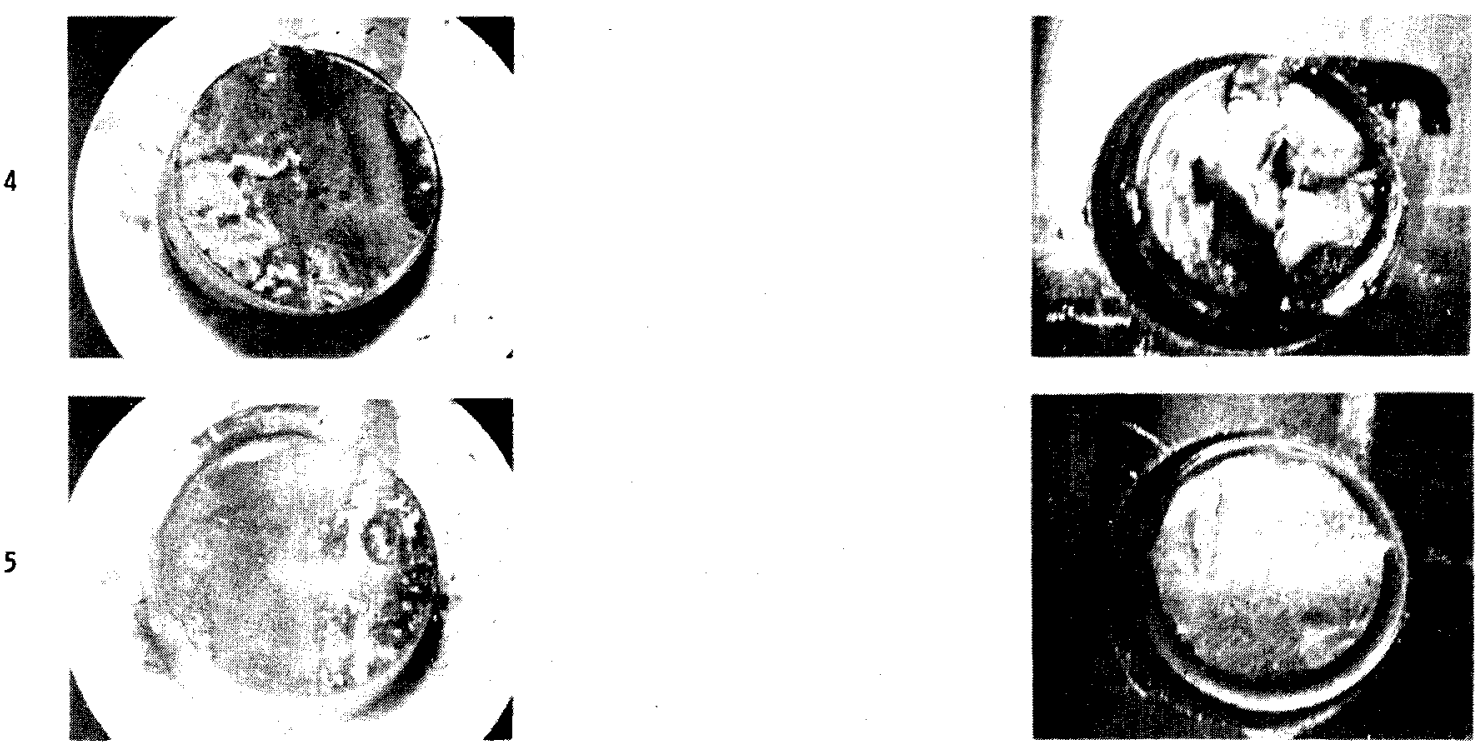

FIGURE 7. Core Samples Taken from Canister SS-9 
Figures 8 through 12 show the micrographs of Samples 1 through 5 , respectively. Figures 8 and 70 , containing crack areas, show gross intergranular attack. Figures 9 and 12 show good areas of the canister, and Figure 11 shows the bottom cap weld. This sample had some micro-cracking extending through the weld and into the carister wall. All the polished areas examined were free of transgranular cracking, a stress corrosion cracking indicator. Samples taken from areas free of macro-cracks, samples 2 and 5 , were also free of mini-cracks. (5)

After all examinations were completed the lower portion of Canister SS-9 was covered with an overpack before being returned to pod storage. The overpack was TIG weided with a manifulator, while the canister was suspended vertically. The 3/8-in. thick $3,04 \mathrm{~L}$ stainless steel overpack was tack welded and then sequence welded. Some undercutting of the canister metal was observed during welding. The canister was vacuum dried; the overpack was then helium leak-checked. The canister was returned to the water test pod and high activity in the storage water has not been seen. (7)

Canister SS-9 was in a stressed condition after being filled with phosphate ceramic product. The coefficients of thermal expansion for the phosphate glass, and 310 steel canister are $6 \times 10^{-6} \frac{\mathrm{in} .{ }^{\circ}}{\mathrm{in} .{ }^{\circ} \mathrm{C}}$ and $14.4 \times$

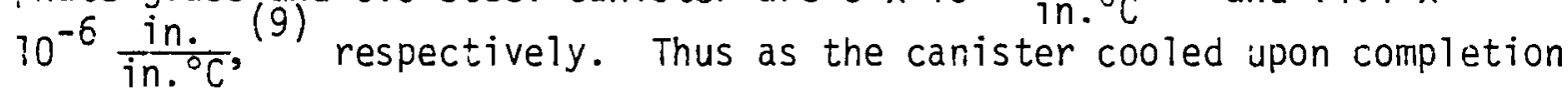
of the run, it became highly stressed since the glass prevented its normal contraction. The storage period in hot air was ideal for sensitization, causing carbon and chrome migration to the grain boundaries and formation of chrome carbide intergranularly. This made the canister very susceptibie to intergranular attack. During water storage, a significant chloride concentration of $13 \mathrm{ppm}$ was found, which was conducive to strass corrosion.

In conclusion, it can be seen from this evaluation that 310 stainless steel becomes highly sensitized after prolonged air storage at alevated temperatures and should not he subsequently stored in water. The faijure of the canister appears to have been caused by stress-assisted intergrariular attack enhanced by the high chloride concentration in the pod storage water. 


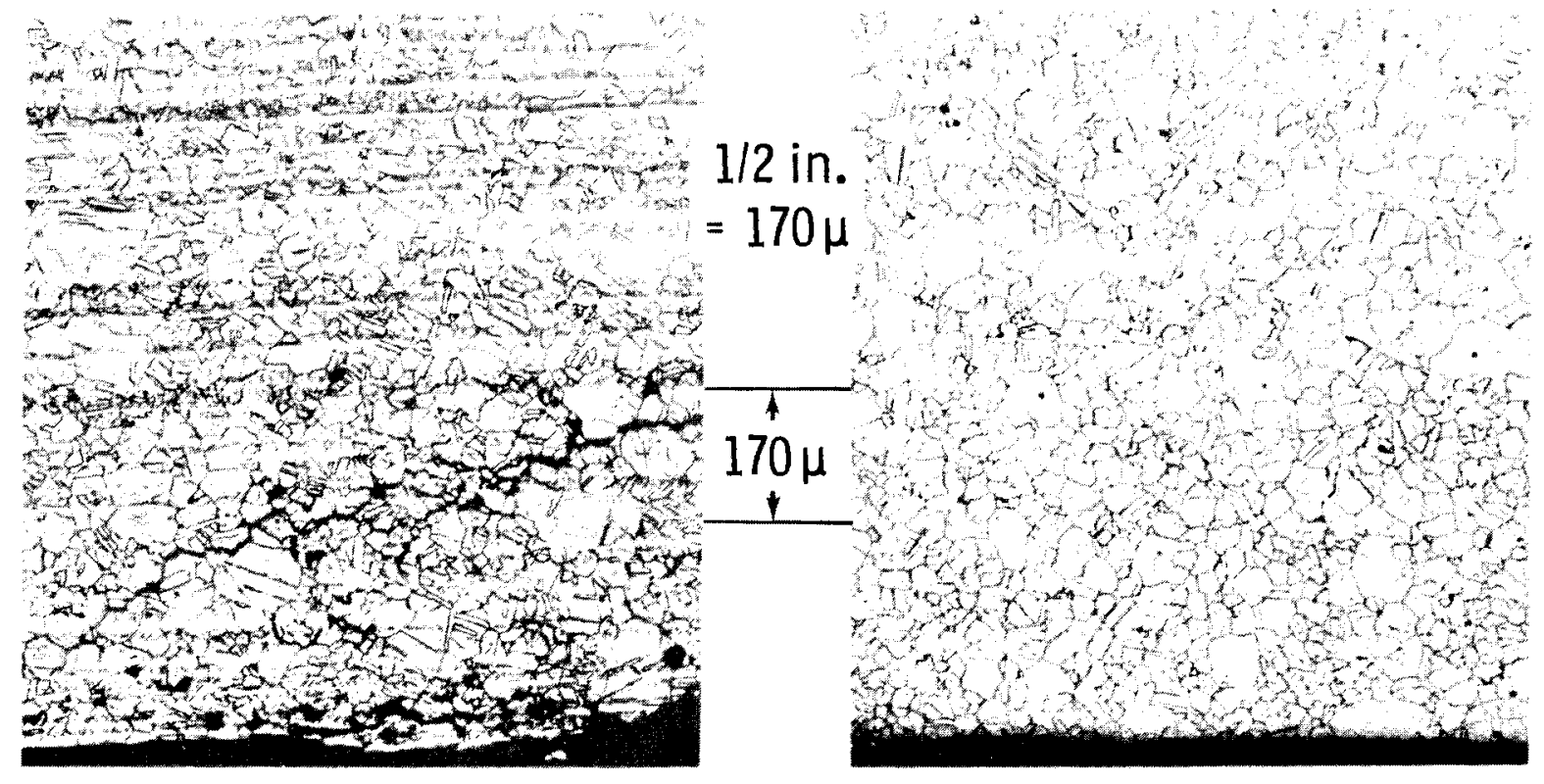

\section{INTERNAL SURFACE EDGE 75X EXTERNAL SURFACE EDGE $75 X$}

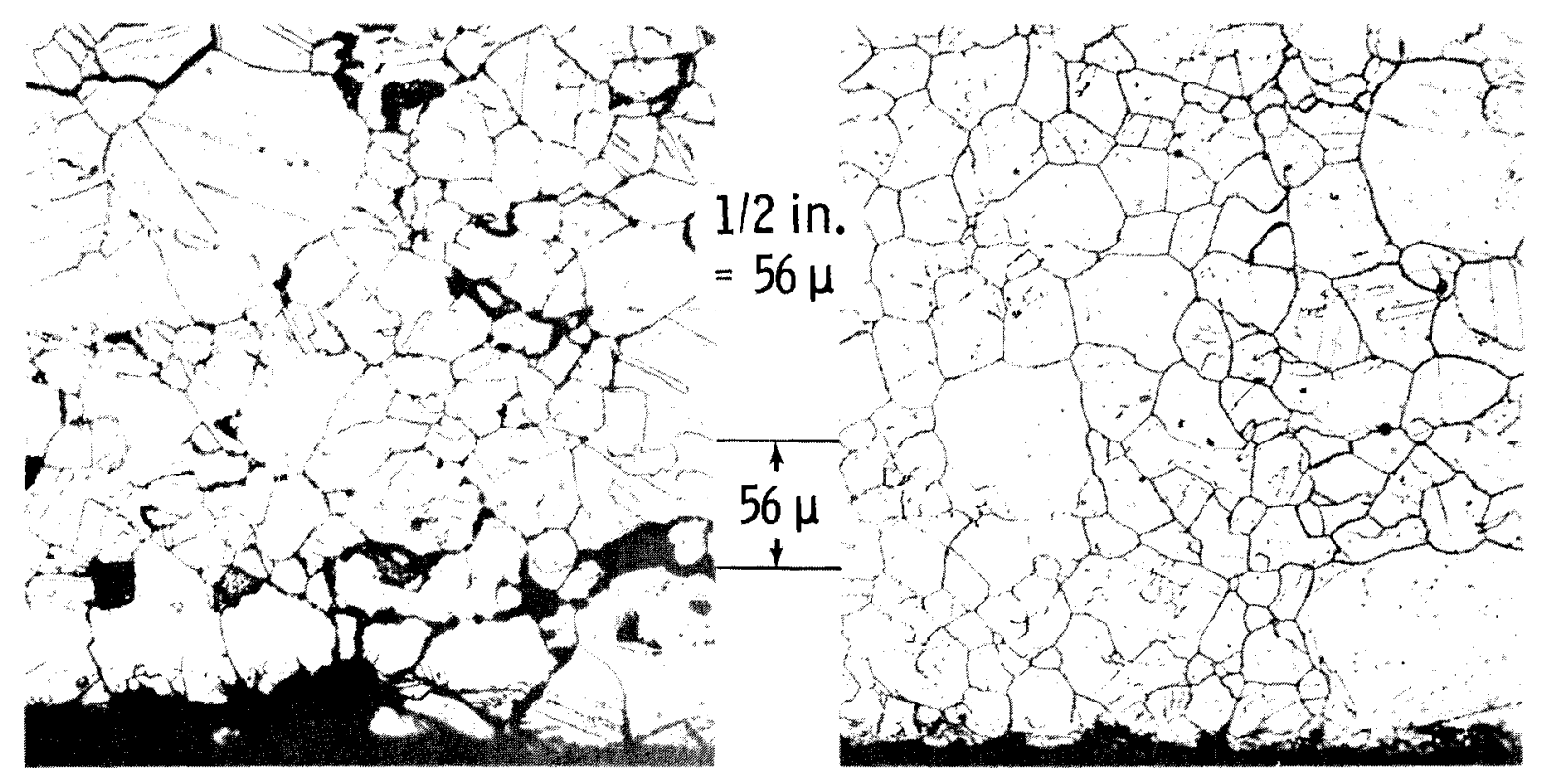

\section{INTERNAL SURFACE EDGE 225X EXTERNAL SURFACE EDGE $225 \mathrm{X}$}

FIGURE 8. Photomicrographs of Canister Wall Section from WSEP Canister SS-9 Sample Area \#1 (0xalic Acid Electrolytic Etch) 


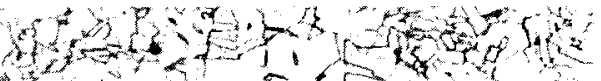

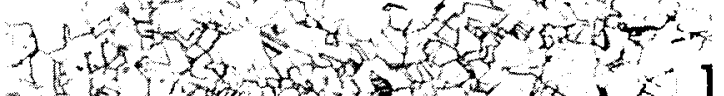

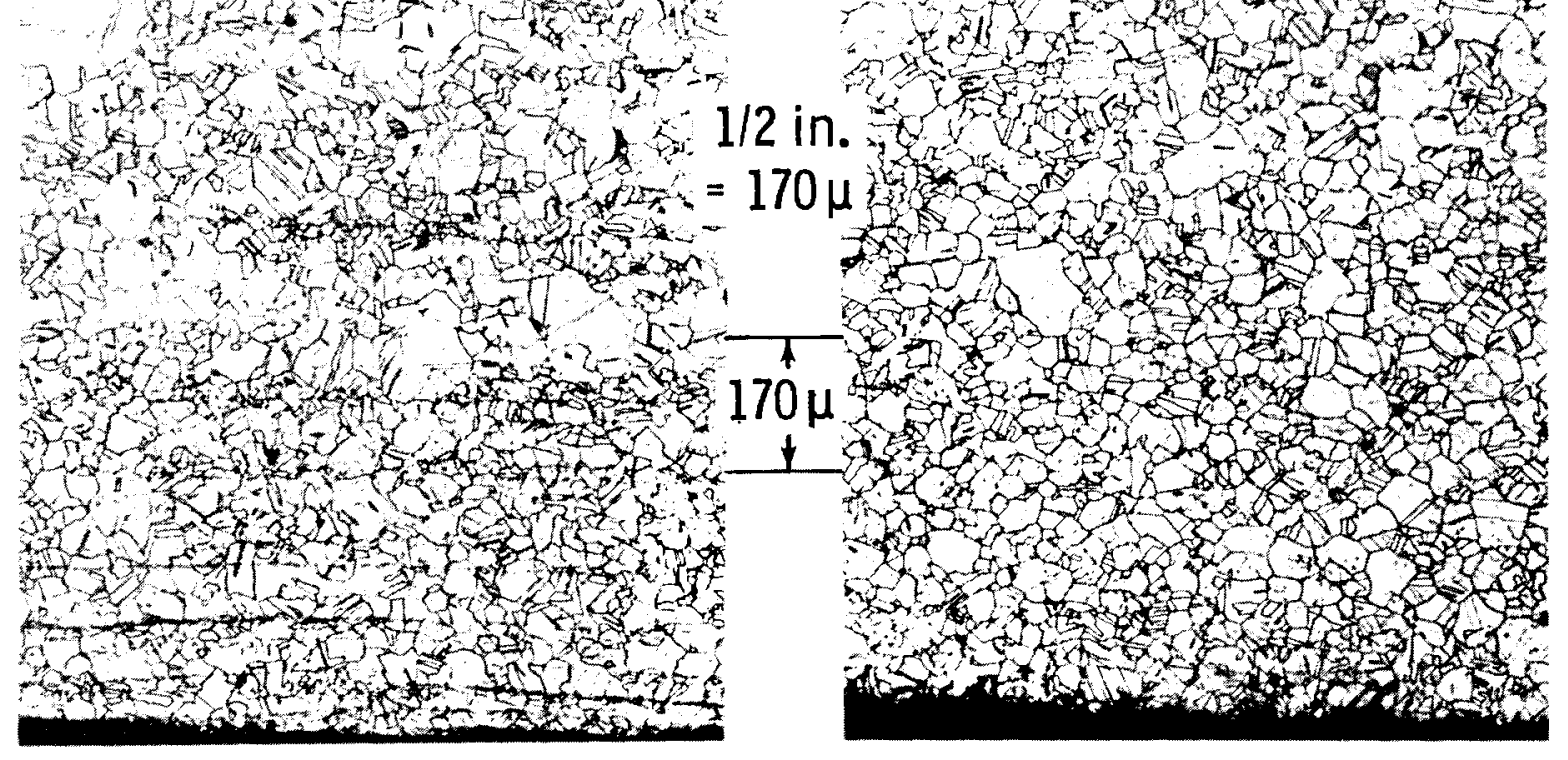

\section{INTERNAL SURFACE EDGE $\quad 75 X \quad$ EXTERNAL SURFACE EDGE $75 X$}

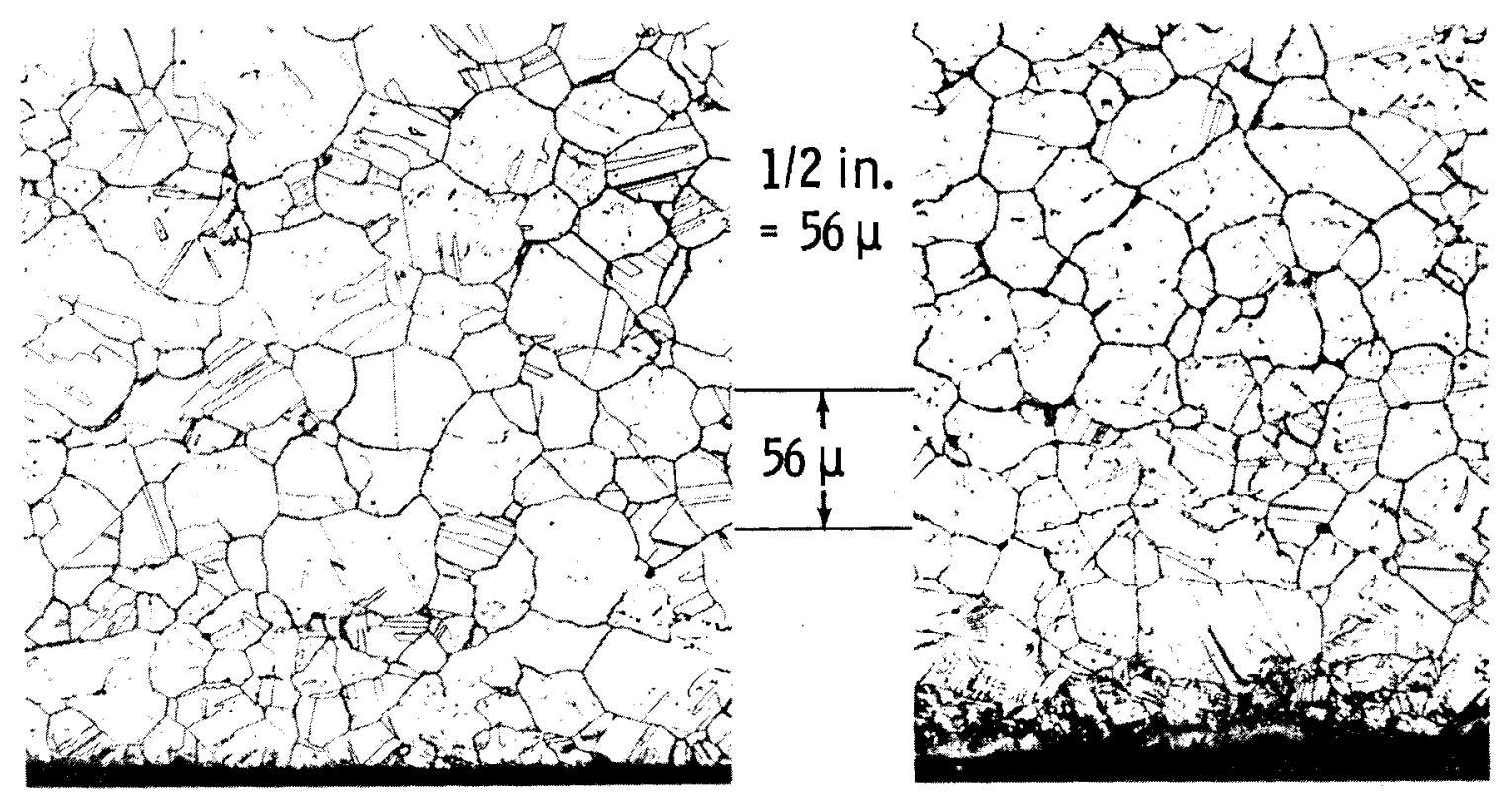

INTERNAL SURFACE EDGE $225 X \quad$ EXTERNAL SURFACE EDGE $225 \mathrm{X}$

FIGURE 9. Photomicrographs of Canister Wa11 Section from WSEP Canister SS-9 Sample Area \#2 (Oxalic Acid Electrolytic Etch) 


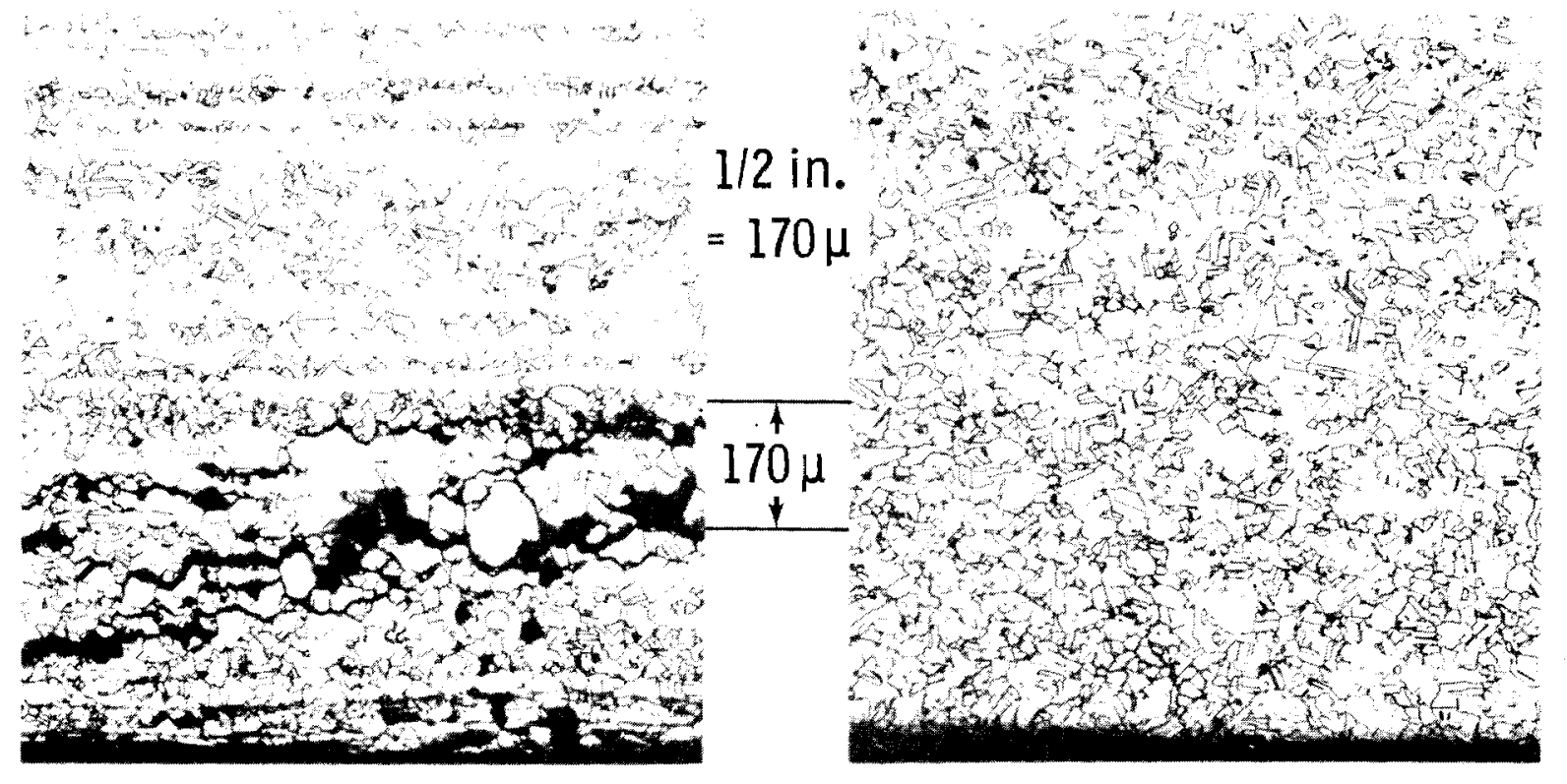

INTERNAL SURFACE EDGE $75 X$ EXTERNAL SURFACE EDGE $75 X$

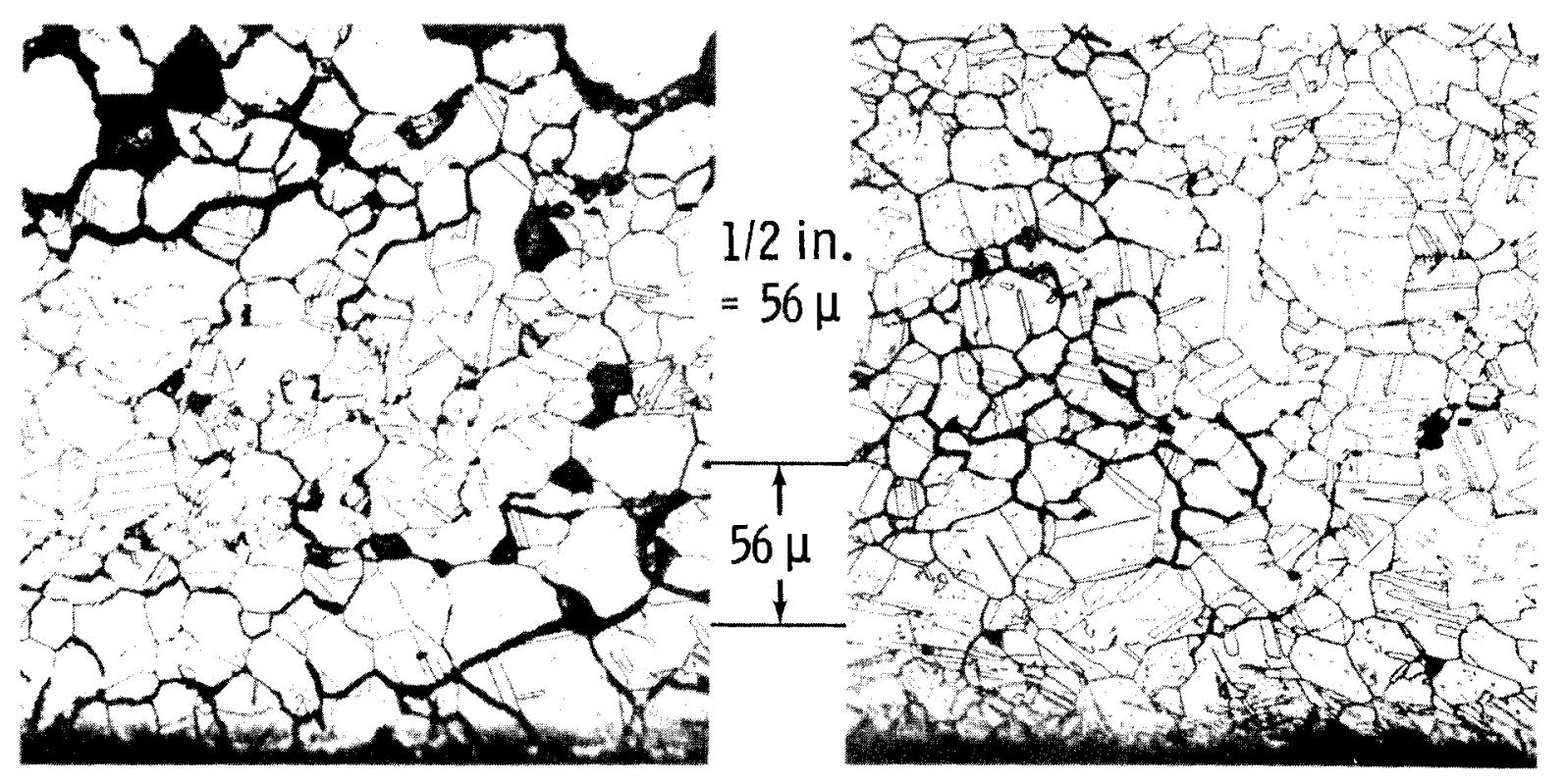

INTERNAL SURFACE EDGE $225 \mathrm{X}$ EXTERNAL SURFACE EDGE $225 \mathrm{X}$

FIGURE 10. Photomicrographs of Canister Wal1 Section from WSEP Canister SS-9 Sample Area \#3 (Oxalic Acid Electrolytic Etch) 


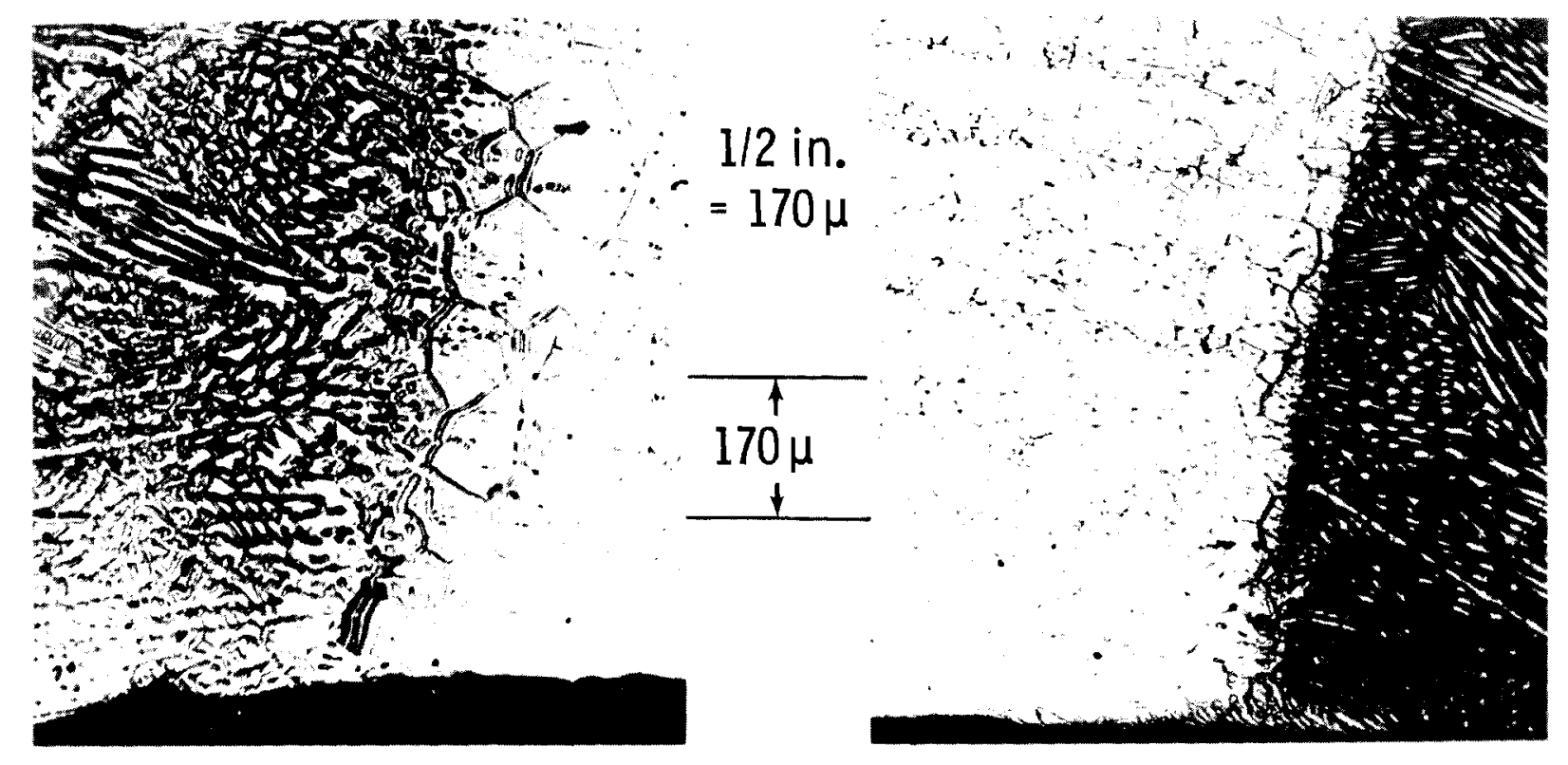

\section{INTERNAL SURFACE EDGE $\quad 75 X \quad$ EXTERNAL SURFACE EDGE $75 \mathrm{X}$}

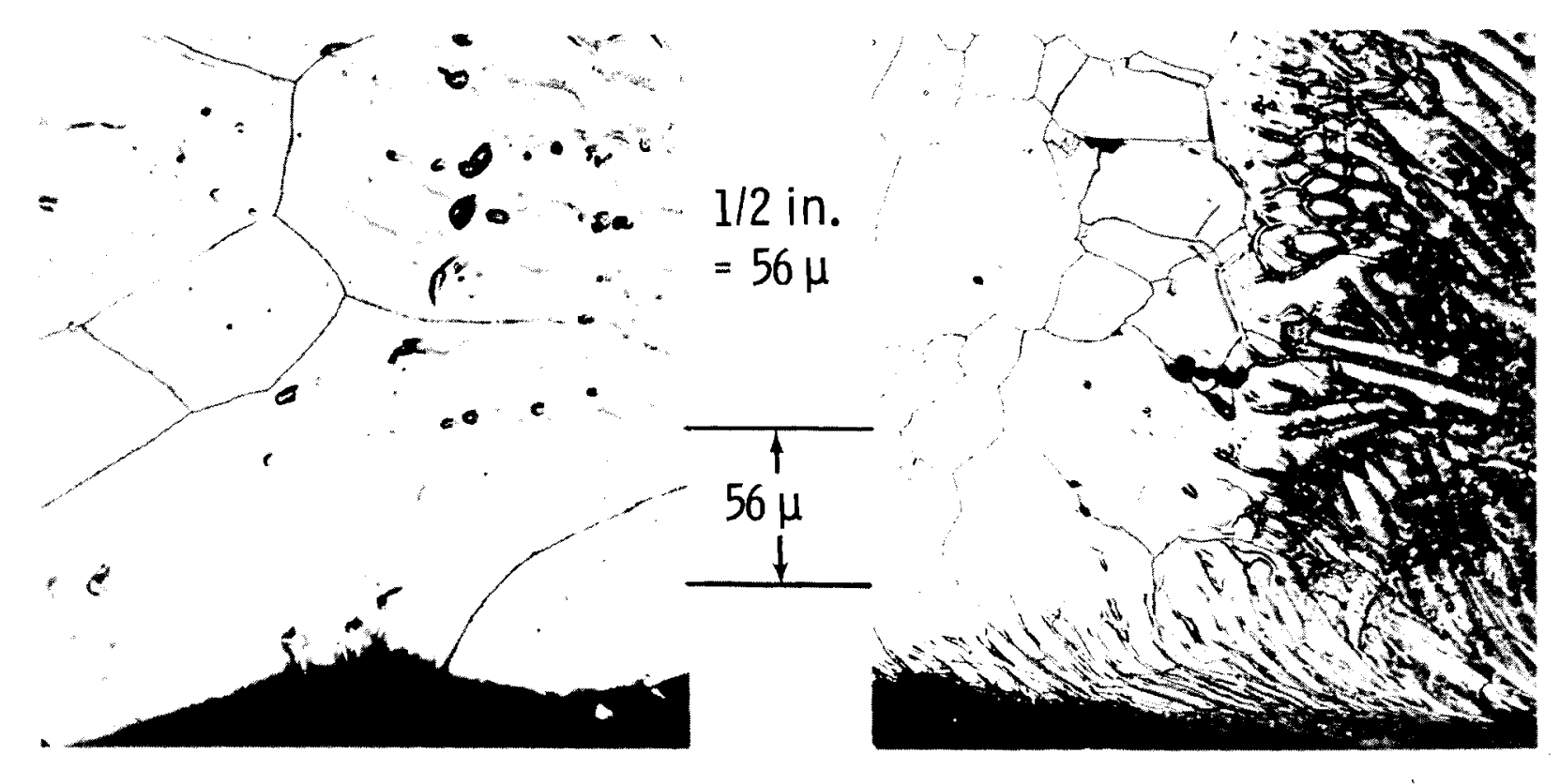

\section{INTERNAL SURFACE EDGE $225 \mathrm{X}$ EXTERNAL SURFACE EDGE $225 \mathrm{X}$}

FIGURE 11. Photomicrographs of Canister Wall Section from WSEP Canister SS-9 Sample Area \#4 (Oxalic Acid Electrolytic Etch) 


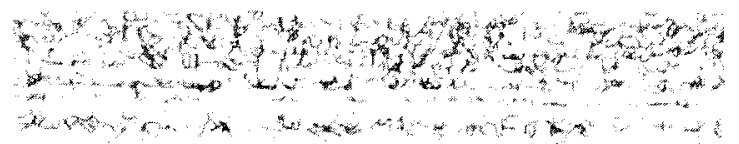

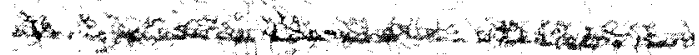

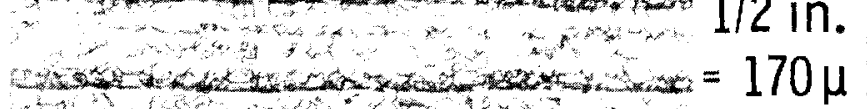

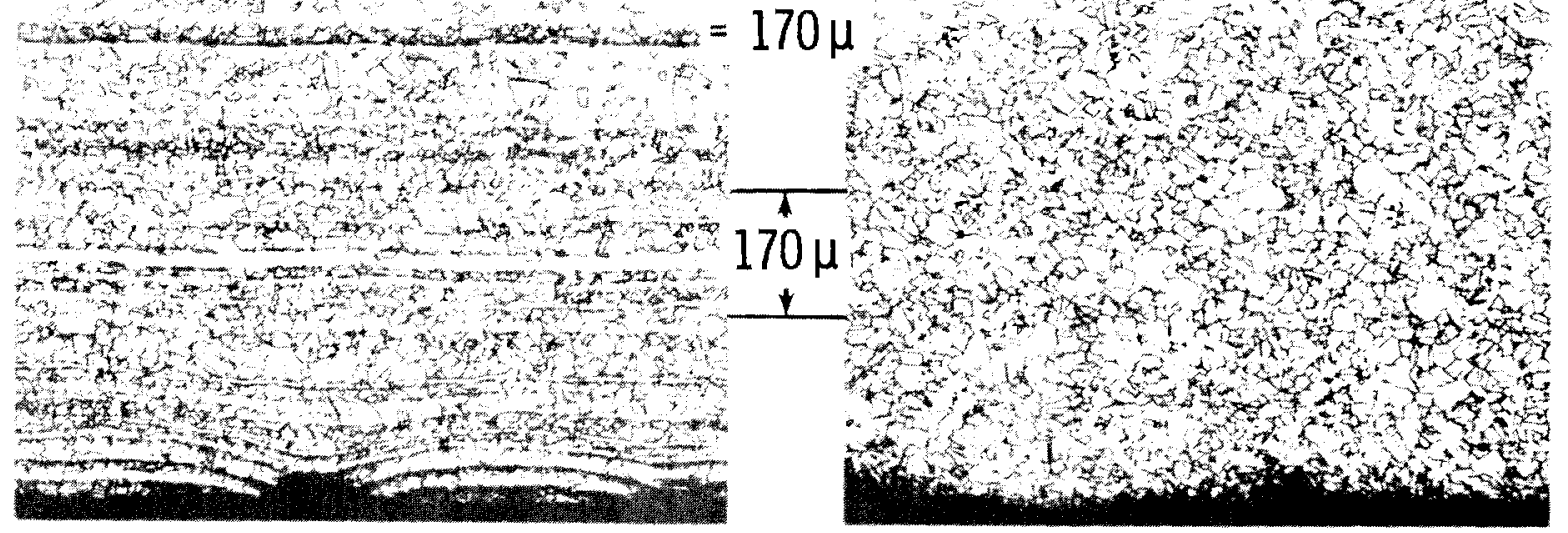

\section{INTERNAL SURFACE EDGE $75 X \quad$ EXTERNAL SURFACE EDGE $75 X$}

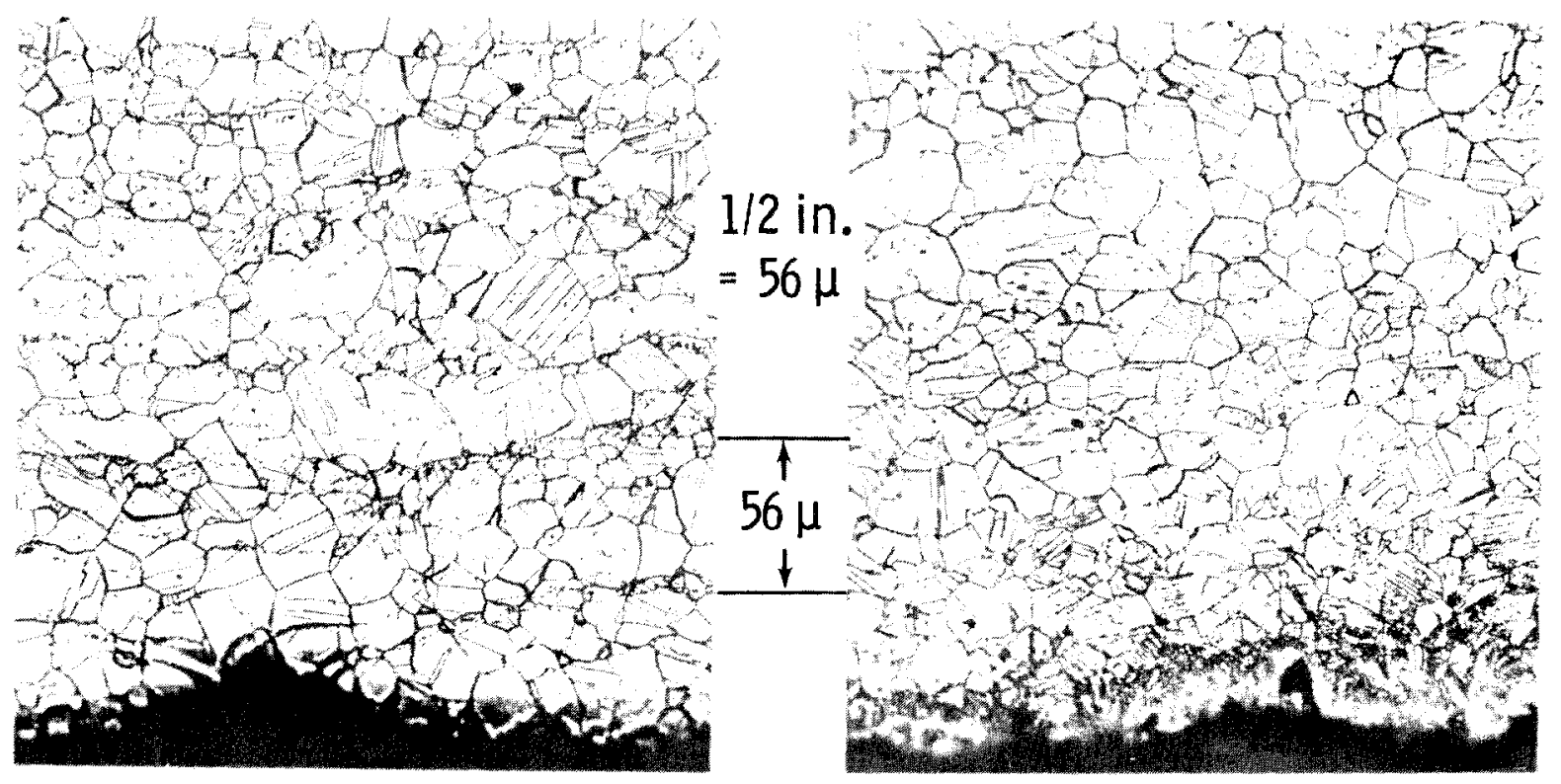

\section{INTERNAL SURFACE EDGE $225 \mathrm{X}$ EXTERNAL SURFACE EDGE $225 \mathrm{X}$}

FIGURE 12. Photomicrographs of Canister Wall Section from WSEP Canister SS-9 Sample Area \#5 (Oxalic Acid Electrolytic Etch) 


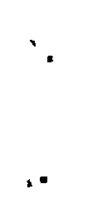


In August 1976, Canister SS-9 was core drilled to remove phosphate ceramic material for leach testing. Three cores $1.91 \mathrm{~cm}$ in diameter were taken; their location and characteristics are given in Table 10.

\section{TABLE 10. Canister SS-9 Core Sample Measurements}

\begin{tabular}{|c|c|c|c|c|c|}
\hline $\begin{array}{l}\text { Sample } \\
\text { Number }\end{array}$ & $\begin{array}{c}\text { Distance } \\
\text { from Bottomi } \\
\text { of Canister, } \\
\mathrm{cm} \\
\end{array}$ & $\begin{array}{l}\text { Radial } \\
\text { Location, } \\
\text { degrees }\end{array}$ & $\begin{array}{l}\text { Sample } \\
\text { Weignt, } \\
\quad 9 \\
\end{array}$ & $\begin{array}{l}\text { Geometric } \\
\text { Sample } \\
\text { Surfacs } \\
\text { Area, } \\
\mathrm{cm}^{2} \\
\end{array}$ & $\begin{array}{c}\text { Sample } \\
\text { volume, } \\
\mathrm{cm}^{2}\end{array}$ \\
\hline SS-9-1 & 186.4 & 180 & 17.880 & 29.4 & $1 ? .0$ \\
\hline SS-9-2 & 110.2 & 180 & 16.803 & 32.3 & 9.8 \\
\hline SS-9-3 & 54.3 & 180 & 28.942 & 58.1 & 14.8 \\
\hline
\end{tabular}

Figure 13 shows photographs of the three cores used for leaching. The cores were then placed in a Paige leaching apparatus, as shown in Figure 14 , for contact with deionized water. In the Paige test, the sample is contacted with the recirculating leachant at ambient temperatures. The effects of the small change in surface area during leaching were not considered in this study.

The solutions were sampled and changed according to the time schedule given in Table 11.

TABLE 11. Leaching Schedule

\begin{tabular}{cccc}
$\begin{array}{c}\text { Sample } \\
\text { Series } \\
\text { Number }\end{array}$ & $\begin{array}{c}\text { Cumulative } \\
\text { Leach } \\
\text { Time, } \\
\text { days }\end{array}$ & $\begin{array}{c}\text { Sample } \\
\text { Leach } \\
\text { Time, } \\
\text { days }\end{array}$ & $\begin{array}{c}\text { Date } \\
\text { Sampled }\end{array}$ \\
\cline { 1 - 2 } 1 & 1 & 1 & $08-24-76$ \\
2 & 2 & 1 & $08-25-76$ \\
3 & 3 & 1 & $08-26-75$ \\
4 & 4 & 1 & $08-27-76$ \\
5 & 7 & 3 & $08-30-75$ \\
5 & 15 & 3 & $09-07-76$ \\
7 & 27 & 6 & $09-13-76$ \\
8 & 23 & 7 & $09-20-76$ \\
9 & 58 & 30 & $10-20-76$ \\
10 & 84 & 26 & $11-15-76$ \\
11 & 113 & 29 & $12-13-76$ \\
12 & 145 & 32 & $01-14-76$ \\
13 & 173 & 23 & $02-11-77$ \\
14 & 199 & 26 & $03-08-77$
\end{tabular}



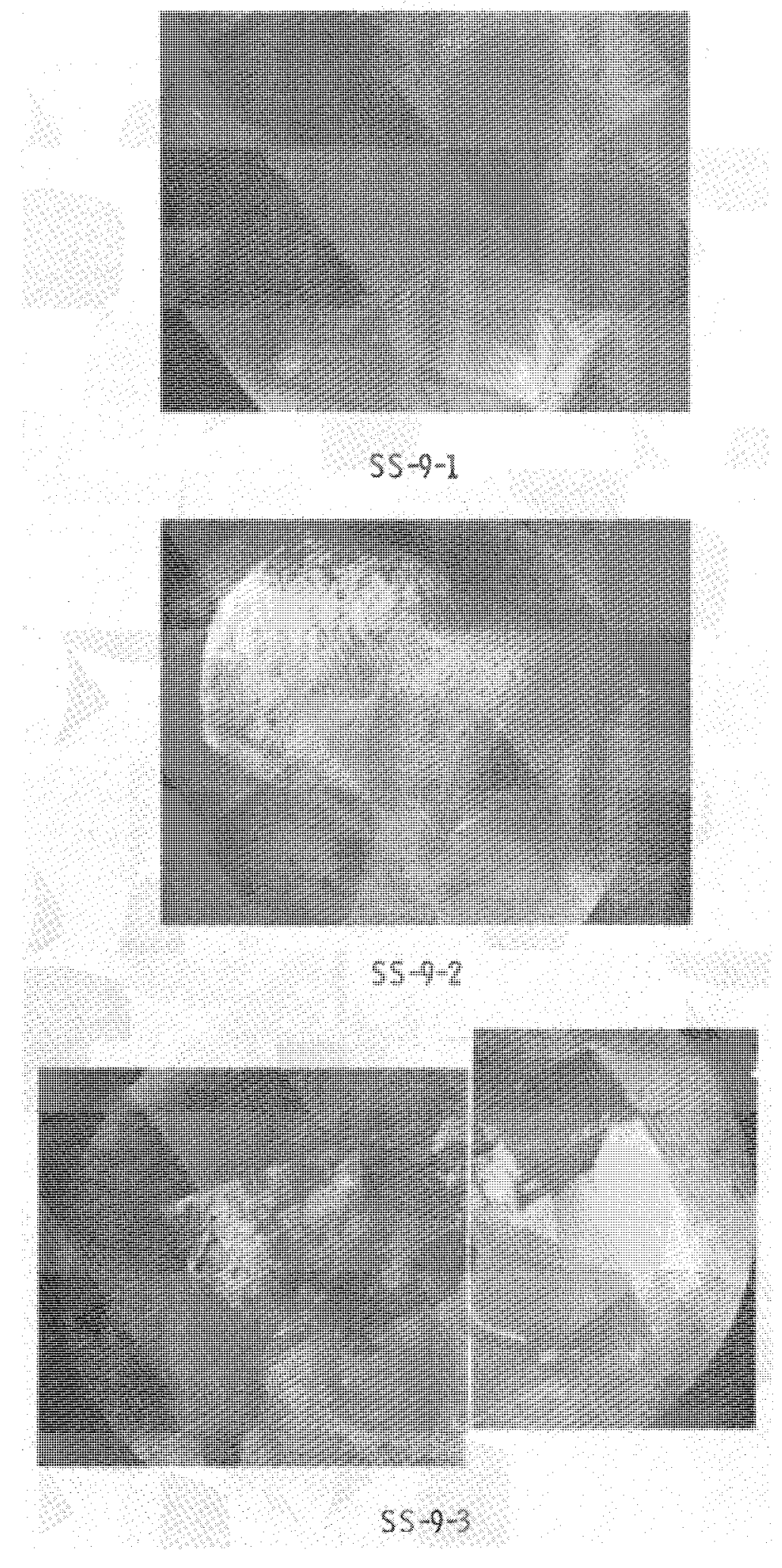

FIGURE 13. Core Samples for Leaching Experiments 


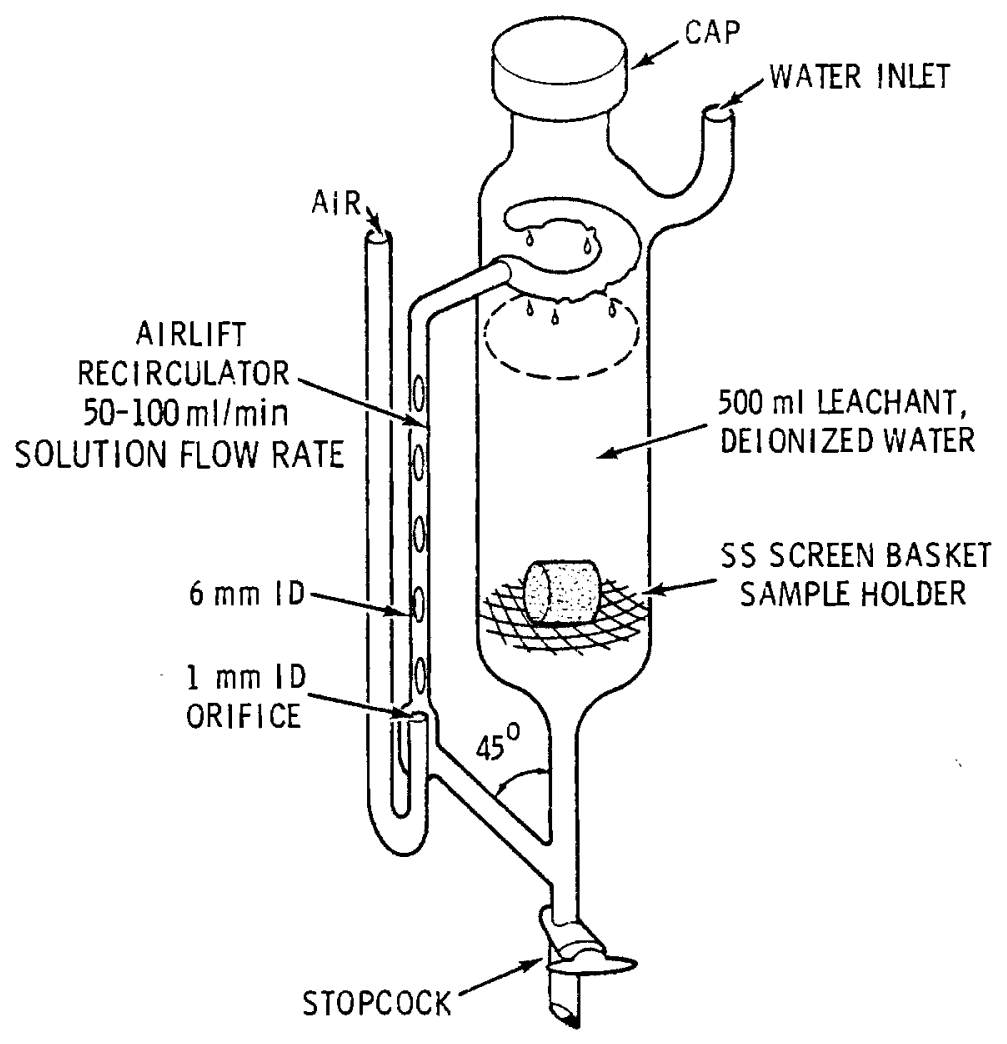

FIGURE 14. Paige Leaching Apparatus

The leach solutions were analyzed by gamma spectroscopy for ${ }^{137} \mathrm{Cs}$. Leach rates were then calculated according to the formula

$$
R=\frac{a_{0}}{A_{0} S \Delta T}
$$

where $R=$ leach rate in $\mathrm{g} / \mathrm{cm}^{2}$ per day

$$
\begin{aligned}
a_{0} & =\text { disintegration/min for total leach solution } \\
A_{0} & =\text { disintegration/min for total sample } \\
S & =\text { sample surface area, } \mathrm{cm}^{2} \\
\Delta T & =\text { leach time, days. }
\end{aligned}
$$

Table 12 shows the results of the leach rate calculations for samples SS-9-1 through SS-9-3. Figure 15 shows these results plotted together. The leaching studies were done to obtain a leach rate for the phosphate 
ceramic material so that a correlation could be made back to the measurements taken when the canister failed. Knowing the leachate activity at the time of failure in $\mathrm{mr} / \mathrm{hr}$, (see Page 9 ) the conversion factor between $\mathrm{mr} / \mathrm{hr}$ and disintegrations per minute for the leach solution, and the leach rate of the material allows calculation of the effective surface area of waste contacted as a result of the canister failure.

\section{TABLE 12. Leach Rates of Canister SS-9 \\ Phosphate Ceramic Based on 137 Cs}

\begin{tabular}{|c|c|c|c|c|}
\hline \multirow{2}{*}{$\begin{array}{l}\text { Sample } \\
\text { Series } \\
\text { Number }\end{array}$} & \multirow{2}{*}{$\begin{array}{l}\text { Samp ?e } \\
\text { Leach } \\
\text { Time, } \\
\text { days }\end{array}$} & \multicolumn{3}{|c|}{$\begin{array}{l}\text { Leach Rate } \\
\mathrm{g} / \mathrm{cm}^{2} \text { - day }\end{array}$} \\
\hline & & $5 S-9-1$ & $5 S-9-2$ & SS-9-3 \\
\hline 1 & 1 & $8.3 \times 10^{-4}$ & $2.7 \times 10^{-4}$ & $4.2 \times 10^{-4}$ \\
\hline 2 & 1 & $3.8 \times 10^{-4}$ & $1.1 \times 10^{-4}$ & $2.2 \times 10^{-4}$ \\
\hline 3 & 1 & $1.8 \times 10^{-4}$ & $5.4 \times 10^{-5}$ & $1.4 \times 10^{-4}$ \\
\hline 4 & 1 & $1.0 \times 10^{-4}$ & $4.5 \times 10^{-5}$ & $1.4 \times 10^{-4}$ \\
\hline 5 & 3 & $5.5 \times 10^{-5}$ & $3.1 \times 10^{-5}$ & $7.8 \times 10^{-}$ \\
\hline 6 & 8 & $3.0 \times 10^{-5}$ & $1.8 \times 10^{-5}$ & $4.7 \times 10^{-5}$ \\
\hline 7 & 6 & $3.1 \times 10^{-5}$ & $1.9 \times 10^{-5}$ & $3.9 \times 10^{-5}$ \\
\hline 8 & 7 & $3.1 \times 10^{-5}$ & $1.8 \times 10^{-5}$ & $2.9 \times 10^{-5}$ \\
\hline 9 & 30 & $1.9 \times 10^{-5}$ & $8.5 \times 10^{-6}$ & $1.1 \times 10^{-5}$ \\
\hline 10 & 26 & $1.9 \times 10^{-5}$ & $7.4 \times 10^{-6}$ & $8.5 \times 10^{-6}$ \\
\hline 11 & 29 & $1.7 \times 10^{-5}$ & $6.4 \times 10^{-6}$ & $8.2 \times 10^{-6}$ \\
\hline 12 & 32 & $1.4 \times 10^{-5}$ & $5.6 \times 10^{-6}$ & $6.7 \times 10^{-6}$ \\
\hline 13 & 28 & $1.3 \times 10^{-5}$ & $5.5 \times 10^{-6}$ & $6.9 \times 10^{-6}$ \\
\hline 14 & 26 & $1.6 \times 10^{-5}$ & $7.0 \times 10^{-6}$ & $8.0 \times 10^{-}$ \\
\hline
\end{tabular}

The average leach rate for the three samples tested was calculated for the first day and a period of the first 90 days to be $5.1 \times 10^{-4} \mathrm{~g} / \mathrm{cm}^{2}$-day and $3.1 \times 10^{-5} \mathrm{~g} / \mathrm{cm}^{2}$-day, respectively. Because the actual time of failure occurrence was unknown, these average leach rates represent upper and lower boundaries as the failure had to occur sometime during the quarterly sampling period for the canister storage pods. 


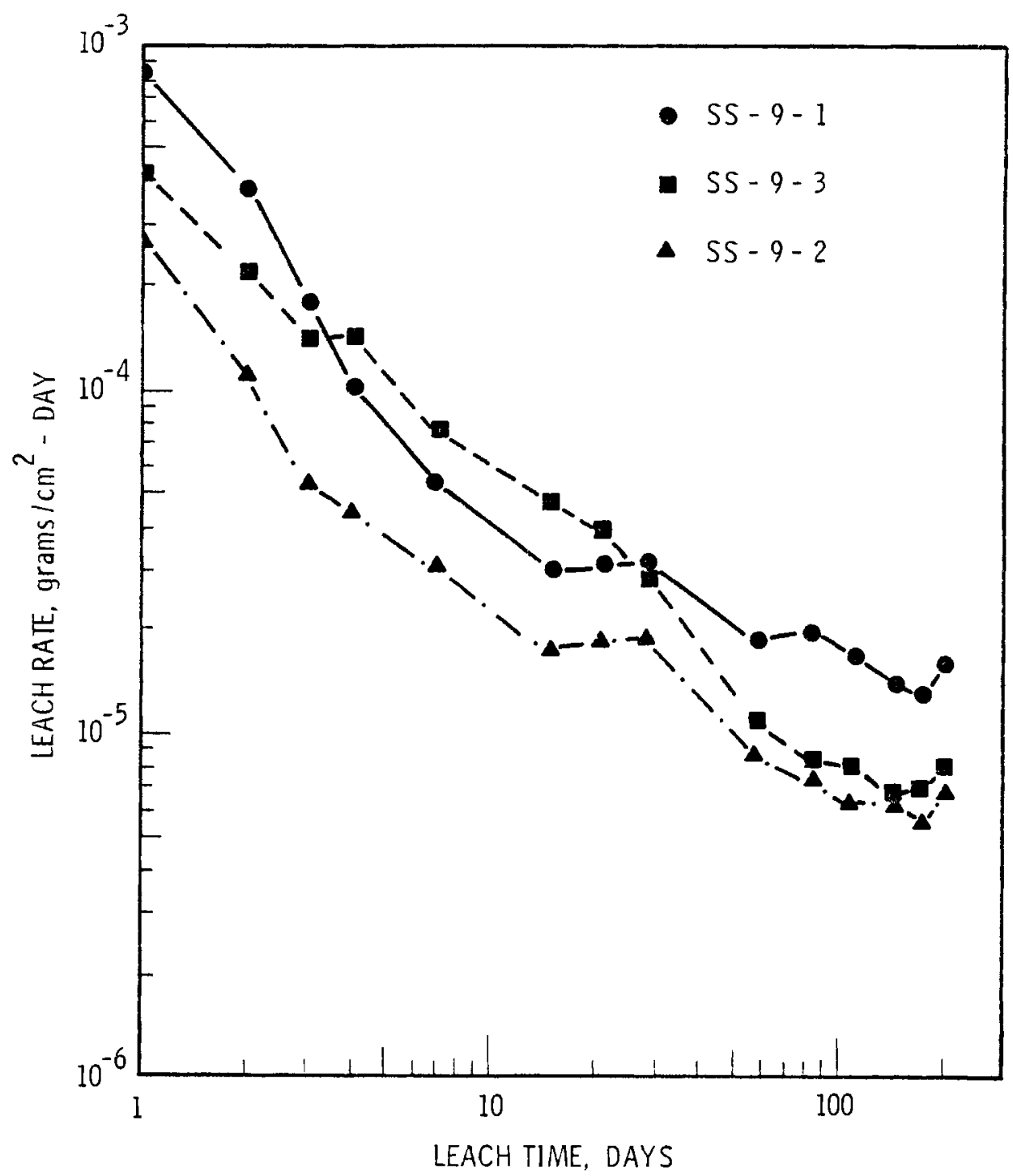

FIGURE 15. Leach Rates of Canister SS-9 Phosphate Ceramic Waste

The conversion factor between $\frac{\text { disintegrations }}{\text { minute }}$ and $\frac{\mathrm{mrem}}{\mathrm{hr}}$ for the SS-9 leach solution was found by experiment to be

$$
1 \frac{\mathrm{mrem}}{\mathrm{hr}}=9.8 \times 10^{6} \frac{\text { disintegrations }}{\text { minute }}
$$

based on ${ }^{137} \mathrm{Cs}$.

The effective waste surface area seen by the leach solution due to the cracks was calculated using the following equation: 


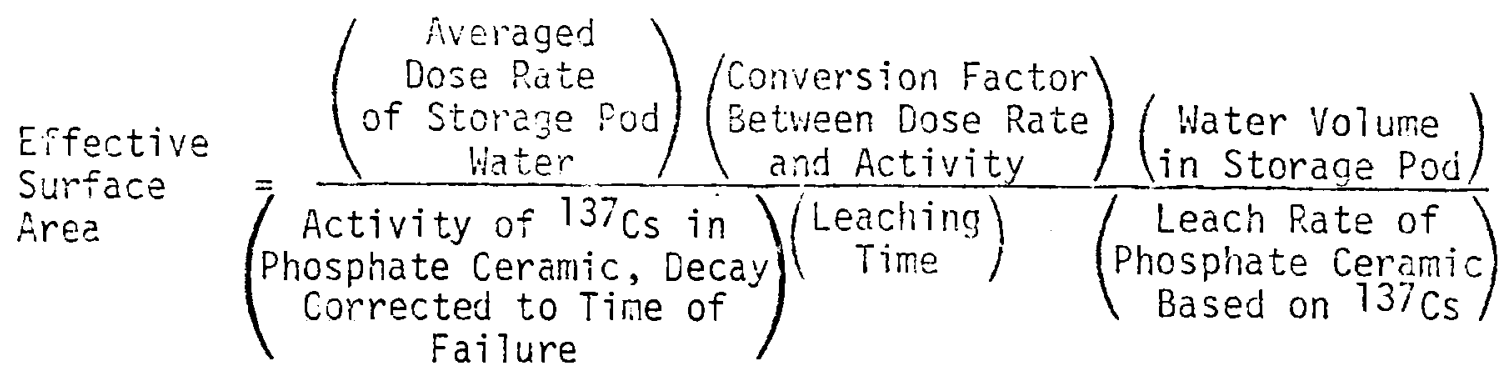

The effective surface areas were calculated to be $1.2 \mathrm{~m}^{2}$ based on averaged first day leach rate, and $19.9 \mathrm{~m}^{2}$ based on averaged leach rate over 90 days. Because of the frequency of pod water sampling, the failure had to occur sometime between 1 and 90 days. The surface area of $1.2 \mathrm{~m}^{2}$ assumes a failure on the day before the storage water was anaiyzed. The surface area of $19.9 \mathrm{~m}^{2}$ corresponds to a failure one day after the previous pod water sampling. Thus, these numbers represent the extremes of the surface areas that could have been contacted. Although the surface area may seem large, this does not necessarily imply deep penetration due to the probable size of the waste particles encountered. Table 13 shows the amounts of various-sized particles needed to yield the surface areas given above. The table also shows data on Canister SS-9.

\section{TABLE 13. Particle Parameters Needed to Yield Effective Surface Areas}

\begin{tabular}{|c|c|c|c|c|c|c|c|}
\hline \multirow{2}{*}{$\begin{array}{l}\text { Mesh } \\
\text { No. }\end{array}$} & \multirow{2}{*}{$\begin{array}{c}\text { Sphere } \\
\text { Radius, } \\
\text { cm }\end{array}$} & \multicolumn{2}{|c|}{$\begin{array}{l}\text { Particies Needed } \\
\text { Based On: }\end{array}$} & \multicolumn{2}{|c|}{$\begin{array}{c}\text { Volume Needed, } \mathrm{cm}^{3} \\
\text { Based On: }\end{array}$} & \multicolumn{2}{|c|}{$\begin{array}{c}\text { Grams Giass Needec } \\
\text { Based On: }\end{array}$} \\
\hline & & 1 day & 90 days & 1 day & 90 days & I day & 90 days \\
\hline 10 & $1.0 \times 10^{-1}$ & $9.5 \times 10^{4}$ & $1.6 \times 10^{6}$ & 400 & 6630 & 1200 & 19900 \\
\hline 100 & $7.49 \times 10^{-3}$ & $1.7 \times 10^{7}$ & $2.8 \times 10^{8}$ & 30 & 497 & 90 & 1490 \\
\hline 325 & $5.86 \times 10^{-5}$ & $2.8 \times 10^{1 ?}$ & $4.6 \times 10^{12}$ & 0.24 & 3.9 & 0.72 & 17.7 \\
\hline
\end{tabular}

Note:

- Surface Area Canister $\$ 5-9=1.35 \mathrm{~m}^{2}$

- Volume of Canister $55-9=68,400 \mathrm{~cm}^{3}$

- Mass of Phosphate Ceramic in Canister $55-9=198,300 \mathrm{~g}$. 
Based on the calculated effective surface area and the leach rate of the phosphate ceramic material, $6.1 \mathrm{~g}$ of waste were dissolved per day. This is related to the activity of the canister as follows:

- Curies of ${ }^{137}$ CS in Canister SS-9 (corrected to May 1977) $=1.78 \times 10^{4}$

- Curies of ${ }^{137}$ Cs leached in one day $=0.55$ curies Percent of total canister $\quad=0.0031$

- Curies of ${ }^{137}$ Cs leached in 90 days $=49.4$ curies Percent of total canister $\quad=0.28$

Assuming a failed canister of the same magnitude as Canister SS-9, an idea of its effect on a water storage basin can be shown. Consider the following assumptions:

- Storage basin is $36 \mathrm{ft}$ long, $19 \mathrm{ft}$ wide, and $38 \mathrm{ft}$ deep.

- Water volume, after subtracting five hundred $1 \mathrm{ft}$ diameter $\times 10 \mathrm{ft}$ long canisters, is $6.25 \times 10^{5}$ liters.

- Released radioactivity is homogeneously distributed throughout the storage basin.

- Fractional release of ${ }^{137}$ Cs as given above for one leaking canister in the storage basin.

Given these assumptions, Table 14 shows the expected activity in the storage basin for a 1-day and a 90-day release.

TABLE 14. Water Storage Basin Activity from One Failed Canister Based on ${ }^{137} \mathrm{Cs}$

\begin{tabular}{|c|c|c|c|}
\hline \multirow[b]{2}{*}{$\begin{array}{l}\text { Release } \\
\text { Time }\end{array}$} & \multicolumn{3}{|c|}{ Activity of Water } \\
\hline & $\mu \mathrm{C} / 2$ & $\frac{\text { dis }}{\min -2}$ & $\frac{m r e m}{h r-\ell}$ \\
\hline & 0.88 & $1.96 \times 10^{6}$ & 0.20 \\
\hline 90 days & 79 & $1.76 \times 10^{8}$ & 18 \\
\hline
\end{tabular}

The activities given in Table 14 do not consider the use of ion exchange systems, which are an integral part of water storage basins. 
.. 


\section{REFERENCES}

1. J. E. Mendel and J. L. McElroy, Waste Solidification Program, Vol. 10, Evaluation of Solidified Waste Products. BNWL-1666, Batte1le, Pacific Northwest Laboratories, Richland, WA 99352, July 1972.

2. J. L. McElroy et a1., Waste Solidification Program Summary Report, Vol. 11, Evaluation of WSEP High Level Waste Solidification Processes. BNWL-1667, Battel1e, Pacific Northwest Laboratories, Richland, WA 99352 , July 1972.

3. M. J. Be1l, ORIGEN - The ORNL Isotope Generation and Depletion Code. ORNL-4628, Oak Ridge National Laboratory, Oak Ridge, TN, May 1973.

4. M. G. Fontana and N. D. Greene, Corrosion Engineering. McGraw-Hill Book Co., New York, NY, 1967.

5. J. L. McElroy, ed., Quarterly Progress Report, Research and Development Activities, Waste Fixation Program, 9/74 to 12/74. BNWL-1893, Battelle, Pacific Northwest Laboratories, Richland, WA 99352 , February 1975.

6. J. L. McElroy, ed., Quarterly Progress Report, Research and Development Activities, Waste Fixation Program, 4/75 to 6/75. BNWL-1932, Battelle, Pacific Northwest Laboratories, Richland, WA 99352 , September 1975.

7. J. L. McElroy, ed., Quarterly Progress Report, Research and Development Activities, Waste Fixation Program, $1 / 75$ to 3/75. BNWL-1908, Battelle, Pacific Northwest Laboratories, Richland, WA 99352 , June 1975.

8. R. J. Thompson, J. E. Mendel, and J. H. Klempeter, Waste Solidification Demonstration Program: Characterization of Nonradioactive Samples of Solidified High-Level Waste. BNWL-1393, Battelle, Pacific Northwest Laboratories, Richland, WA 99352, June 1970.

9. R. H. Perry, C. H. Chilton, and S. D. Kirkpatrick, Chemical Engineers: Handbook. 4th ed., McGraw-Hill Book Co., New York, NY, 1963. 


\section{ACKNOWLEDGMENTS}

The author is indebted to J. E. Mendel, W. A. Ross, J. H. Westik, and Y. B. Katayama for their help and suggestions, and to C. E. Bigelow for photography and working experience on Canister SS-9. 


\section{DISTRIBUTION}

No. of

Copies

OFFSITE

A. A. Churm

DOE Chicago Patent Group

9800 South Cass Avenue

Argonne, IL 60439

\section{DOE Technical Information Center}

S. H. Smiley

Deputy Director for

Fuels and Materials

NRC Directorate of Licensing

for Fuels and Materials

4915 St. Elmo Ave.

Bethesda, MD 20014

W. P. Bishop

Chief, Waste Management Branch

NRC Division of Materials and

Fuel cycle Facility Licensing

Washington, DC 20555

W. G. Belter

DOE Division of Biomedical and

Environmental Research

Earth Sciences Branch

Washington, DC 20545

W. A. Brobst

DOE Division of Environmental

Control Technology

Washington, DC 20545

W. E. Mott

DOE Division of Environmental

Control Technology

Washington, DC 20545

G. W. Cunningham

Director, DOE Division of Waste

Management, Production and

Reprocessing

Washington, DC 20545
No. of

Copies

R. B. Chitwood

Chief, LWR Technology Branch

DOE Division of Waste Management,

Production and Reprocessing

Washington, DC 20545

C. R. Cooley

DOE Division of Waste Management,

Production and Reprocessing

Washington, DC 20545

R. A. Wolfe

DOE Division of Waste Management,

Production and Reprocessing

Washington, DC 20545

G. Wehmann

DOE Idaho Operations Office

P. 0. Box 2108

Idaho Falls, ID 83401

DOE Oak Ridge Operations Office

P. 0 . Box $X$

Oak Ridge, TN 37830

J. L. Jardine

M. J. Steindler/L. E. Trevorrow

Argonne National Laboratory

9700 South Cass Ave.

Argonne, IL 60439

2 Central Research Library Document Reference Section

Oak Ridge National Laboratory (DOE)

Oak Ridge, TN 37830

3 Los Alamos Scientific Laboratory (DOE)

P. 0. Box 1663

Los Alamos, NM 87544

W. C. McClain

Union Carbide Corporation

Chemical Technology Division

P. 0 . Box $Y$

Oak Ridge, TN 37830 
No. of

Copies

\section{OFFSITE}

C. D. Zerby

Union Carbide Corporation

Nuclear Division

Office of Waste Isolation

P. 0 . Box $Y$

Oak Ridge, TN 37830

G. H. Jenks

Union Carbide Corporation

Nuclear Division

Office of Waste Isolation

P. O. Box $Y$

Oak Ridge, TN 37830

\section{ONISITE}

5 DOE Richland Operations Office

R. B. Goranson

M. J. Shupe

[. J. Squires

M. J. Zamorski

6 Rcckwell Hanford Operations
H. Babad
D. R. Gustafson
R. E. Isaacson
M. J. SzuTinski
D. D. Wodrich
File Copy

Exxon

Richland, WA 99352

S. J. Beard

Westinghouse Hanford Company

A. G. Blasewitz
No. of

Copies

50 Battelle-Northwest

T. W. Ambrose

T. D. Anderson

J. W. Bartlett

D. N. Berger

W. J. Bjorklund

H. T. Blair

W. F. Bonner

D. J. Brad Tey (5)

J. L. Buelt

C. C. Chapman

T. D. Chikalla

R. D Dierks

J. W. Finnigan

A. A. Garrett

M. S. Hanson

J. C. Harti

O. F. Hill

E. R. Irish

J. H. Jarrett

Y. B. Katayama

R. S. Kemper

D. E. Larson

J. M. Lukacs

J. L. McElroy

J. E. Mendel

W. J. Mikols

R. E. Nightingale

D. E. Olesen

C. R. Palmer

A. M. Platt

D. L. Prezbindowski (2)

F. P. Roberts

L. S. Romero

W. A. Ross

J. M. Rus in

E. C. Sherman

D. H. Siemens

R. Treat

R. P. Turcotte

H. H. Van Tliyl

J. H. Westsik, Jr.

L. D. Williams

W. K. Winegardner

Technical Information (5)

Technical Publications 